\title{
Angiotensin II Modulates Salty and Sweet Taste Sensitivities
}

\author{
Noriatsu Shigemura, ${ }^{1}$ Shusuke Iwata, ${ }^{1}$ Keiko Yasumatsu, ${ }^{1}$ Tadahiro Ohkuri, ${ }^{1}$ Nao Horio, ${ }^{1}$ Keisuke Sanematsu, ${ }^{1}$ \\ Ryusuke Yoshida, ${ }^{1}$ Robert F. Margolskee, ${ }^{2}$ and Yuzo Ninomiya ${ }^{1}$ \\ ${ }^{1}$ Section of Oral Neuroscience, Graduate School of Dental Sciences, Kyushu University, Fukuoka 812-8582, Japan and ${ }^{2}$ Monell Chemical Senses Center, \\ Philadelphia, Pennsylvania 19104-3308
}

Understanding the mechanisms underlying gustatory detection of dietary sodium is important for the prevention and treatment of hypertension. Here, we show that Angiotensin II (AngII), a major mediator of body fluid and sodium homeostasis, modulates salty and sweet taste sensitivities, and that this modulation critically influences ingestive behaviors in mice. Gustatory nerve recording demonstrated that AngII suppressed amiloride-sensitive taste responses to NaCl. Surprisingly, AngII also enhanced nerve responses to sweeteners, but had no effect on responses to $\mathrm{KCl}$, sour, bitter, or umami tastants. These effects of AngII on nerve responses were blocked by the angiotensin II type 1 receptor (AT1) antagonist CV11974. In behavioral tests, CV11974 treatment reduced the stimulated high licking rate to $\mathrm{NaCl}$ and sweeteners in water-restricted mice with elevated plasma AngII levels. In taste cells AT1 proteins were coexpressed with $\alpha \mathrm{ENaC}$ (epithelial sodium channel $\alpha$-subunit, an amiloride-sensitive salt taste receptor) or T1r3 (a sweet taste receptor component). These results suggest that the taste organ is a peripheral target of AngII. The specific reduction of amiloride-sensitive salt taste sensitivity by AngII may contribute to increased sodium intake. Furthermore, AngII may contribute to increased energy intake by enhancing sweet responses. The linkage between salty and sweet preferences via AngII signaling may optimize sodium and calorie intakes.

\section{Introduction}

Angiotensin II (AngII), an octapeptide hormone, plays important roles in the regulation of vascular tone, cardiac function, and sodium reabsorption. AngII is also implicated as a potent stimulus for sodium appetite and preference. For example, intracerebroventricular and intravenous infusion of AngII in rat produces dose-dependent salt appetite, and stimulates sodium intake over a range of concentrations normally rejected (Avrith and Fitzsimons, 1980; Fitts and Thunhorst, 1996). The gustatory system provides critical information about the quality and nutritional value of food before it is ingested. Thus, sodium taste sensitivity might be related to such ingestive behaviors induced by AngII. However, the association between salt taste and AngII effects is unclear.

There is growing evidence that taste function is modulated by hormones. Recent studies in mice demonstrated that sweet taste responses are suppressed by leptin, an anorexigenic mediator that reduces food intake by acting on hypothalamic receptors (Kawai et al., 2000; Shigemura et al., 2004; Nakamura et al., 2008), and

Received Dec. 7, 2012; revised Feb. 4, 2013; accepted Feb. 21, 2013.

Author contributions: N.S. and Y.N. designed research; N.S., S.I., K.Y., T.O., N.H., K.S., and R.Y. performed research; R.F.M. contributed unpublished reagents/analytic tools; N.S., S.I., K.Y., T.O., N.H., and Y.N. analyzed data; N.S., R.F.M., and Y.N. wrote the paper.

This research was supported in part by Grants-in-Aid 18077004, 18109013, and 23249081 (Y.N.), 24659828 (N.S.), and 23689076 (R.Y.) for Scientific Research from the Ministry of Education, Culture, Sports, Science and Technology of Japan and the Salt Science Research Foundation 0443 (Y.N.). We also acknowledge Takeda Chemical Industries (Japan) for the gift of CV11974, Dr. Tsuneyuki Yamamoto (Nagasaki International University, Japan) for providing the original stock of CB1-KO mice, and Dr. Yoshiro Ishimaru (University of Tokyo, Japan) for the gift of Pkd2L1 antibody.

The authors declare no competing financial interests.

Correspondence should be addressed to either Yuzo Ninomiya or Noriatsu Shigemura, 3-1-1 Maidashi, Higashiku, Fukuoka 812-8582, Japan, E-mail: yuninom@dent.kyushu-u.ac.jp or shigemura@dent.kyushu-u.ac.jp.

DOI:10.1523/JNEUROSCI.5599-12.2013

Copyright $\odot 2013$ the authors $\quad 0270-6474 / 13 / 336267-11 \$ 15.00 / 0$ enhanced by endocannabinoids, orexigenic mediators that stimulate food intake by acting on its receptors in hypothalamus and limbic forebrain (Yoshida et al., 2010). The reciprocal effects of anorexigenic versus orexigenic hormones on peripheral sweet taste sensitivity may contribute to their opposing actions on food intake and play an important role in regulating energy homeostasis.

Regarding modulation of sodium taste sensitivity, it has been shown that systemic administration of aldosterone (Aldo), which is secreted from the adrenal cortex through the action of AngII, increased the amiloride-sensitive component of responses to $\mathrm{NaCl}$ in the rat chorda tympani nerve (Herness, 1992). Amiloride is an inhibitor of the epithelial sodium channel (ENaC), which has been implicated as a sensor of sodium salt taste from multiple studies (Heck et al., 1984, Chandrashekar et al., 2010). The increased amiloride-sensitive $\mathrm{NaCl}$ responses elicited by Aldo are thought to be due to translocation of $\mathrm{ENaC}$ from intracellular locations to the apical membrane in rat taste cells (Lin et al., 1999). However, such an elevation of the amiloride-sensitive salt responses was found more than a few hours after Aldo administration (Herness, 1992) and might not account for the acute facilitation of sodium ingestion by AngII.

AngII acts on two main receptor subtypes: AT1 and AT2 receptors. AT1 receptors are widely distributed throughout the body, including vascular smooth muscle, kidney, heart, and brain. AT1 receptors are responsible for mediating vasoconstriction and sodium reabsorption (de Gasparo et al., 2000). We hypothesized that if AngII receptors are expressed in peripheral taste cells, circulating AngII may also act as a modulator for amiloride-sensitive salt responses. The regulation by AngII together with Aldo on peripheral salt taste sensitivity would contribute to salt intake and play an important role in sodium 
Table 1. Nucleotide sequences for the primers used in RT-PCR and in situ hybridization

\begin{tabular}{|c|c|c|c|c|c|}
\hline Genes & Accession No. & analysis & Forward & Reverse & Region \\
\hline \multirow[t]{2}{*}{ AT1 } & NM_177322 & RT-PCR & ctcaacccagaaaagcaaa & ggaacaggaagcccaggatg & $352-989$ \\
\hline & & in situ & tgagaccaactcaacccagaaa & gggctcctgaaacttgatgact & $343-1956$ \\
\hline AT2 & NM_007429 & RT-PCR & aaacactggcaactaaaaag & caaggggaactacataagat & $115-664$ \\
\hline \multirow[t]{2}{*}{ Trpm5 } & NM_020277 & RT-PCR & caggaggcacctactcaagc & atccagctgtccagtccaag & $3458-3825$ \\
\hline & & in situ & accttctgatcgecatgttc & ttgaaatgteccgtttagce & $2999-4167$ \\
\hline \multirow[t]{2}{*}{ Pkd2L1 } & NM_181422 & RT-PCR & gaaagagcgggtttctgatg & tctgggacacaactccttcc & $1962-2341$ \\
\hline & & in situ & gaaagagcgggtttctgatg & ccctcagttccagctagtcg & $1962-3159$ \\
\hline$\beta$-actin & NM_007393 & RT-PCR & ggttccgatgccctgaggctc & acttgcggtgcacgatggagg & $840-1199$ \\
\hline
\end{tabular}

homeostasis. To explore this hypothesis, we investigated the expression of AngII receptors in taste tissues and gustatory nerve and behavioral responses to taste stimuli after administration of AngII in mice.

\section{Materials and Methods}

All experimental procedures were performed in accordance with the National Institutes of Health Guide for the Care and Use of Laboratory Animals and approved by the committee for Laboratory Animal Care and Use at Kyushu University, Japan.

Animals. Subjects were adult male and female C57BL/6NCrj [B6, Charles River], T1r3GFP (Damak et al., 2008), Trpm5-GFP (Clapp et al., 2006), and CB1-KO (Ledent et al., 1999; Yoshida et al., 2010) mice (8-16 weeks of age, ranging in weight from 20 to $32 \mathrm{~g}$ ).

Reverse transcription PCR. Reverse transcription (RT)-PCR was performed as described previously (Kawai et al., 2000; Shigemura et al., 2004; Yoshida et al., 2010). Mouse taste buds in peeled epithelium were individually removed from fungiform papillae (FP) and circumvallate papilla (VP) by aspiration with a transfer pipette. One hundred fungiform or circumvallate taste buds from three mice or $1 \times 1 \mathrm{~mm}$ block of the epithelial tissue without taste buds were used to purify RNAs by RNeasy Plus Micro kit (Qiagen). cDNAs were generated by RT [oligo (dT)12-18 primer] with the superscript pre-amplification system (Invitrogen). Genomic DNA did not contribute to the signal as suggested by two protocols: (1) RNA was treated in parallel in the presence and absence of reverse transcriptase and (2) primers were chosen to span one or more introns to distinguish PCR products from genomic DNA. Primer sequences for each PCR are shown in Table 1. PCR was performed using the following conditions: $95^{\circ} \mathrm{C}$ for $5 \min \left(1\right.$ cycle); $94^{\circ} \mathrm{C}$ for $15 \mathrm{~s}, 58^{\circ} \mathrm{C}$ for $30 \mathrm{~s}, 68^{\circ} \mathrm{C}$ for $40-80 \mathrm{~s}\left(25-40\right.$ cycles); and $75^{\circ} \mathrm{C}$ for $5 \mathrm{~min}$ ( 1 cycle). Each $20 \mu \mathrm{l}$ of PCR solution contained $0.5 \mathrm{U}$ of TaqDNA polymerase (TaKaRa Ex TaqHS; Takara), $2 \mu$ l of $10 \times$ PCR buffer containing $20 \mathrm{~mm}$ $\mathrm{Mg}^{2+}, 0.2 \mathrm{~mm}$ of each dNTP, and $0.6 \mu \mathrm{m}$ of each primer pair. The resulting amplification products were visualized in a $2 \%$ agarose gel with $0.5 \mu \mathrm{g} / \mathrm{ml}$ ethidium bromide.

In situ hybridization. RNA probes were prepared for in situ hybridization (ISH) as previously described (Shigemura et al., 2004). Primer sequences for ISH are shown in Table 1. RT-PCR fragments were purified and cloned into the pGEM T-Easy vector (Promega), which were confirmed by sequencing and digested with appropriate restriction enzymes. Digoxigenin (DIG)-UTP-labeled antisense and sense RNA probes were generated by in vitro transcription using SP6 or T7 transcription Kit (Roche). Frozen blocks of the dissected tongue from B6 mice embedded in the OCT compound (Sakura Finetechnical) were sectioned into $50 \mu \mathrm{m}$.
B

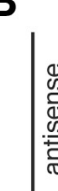

VP
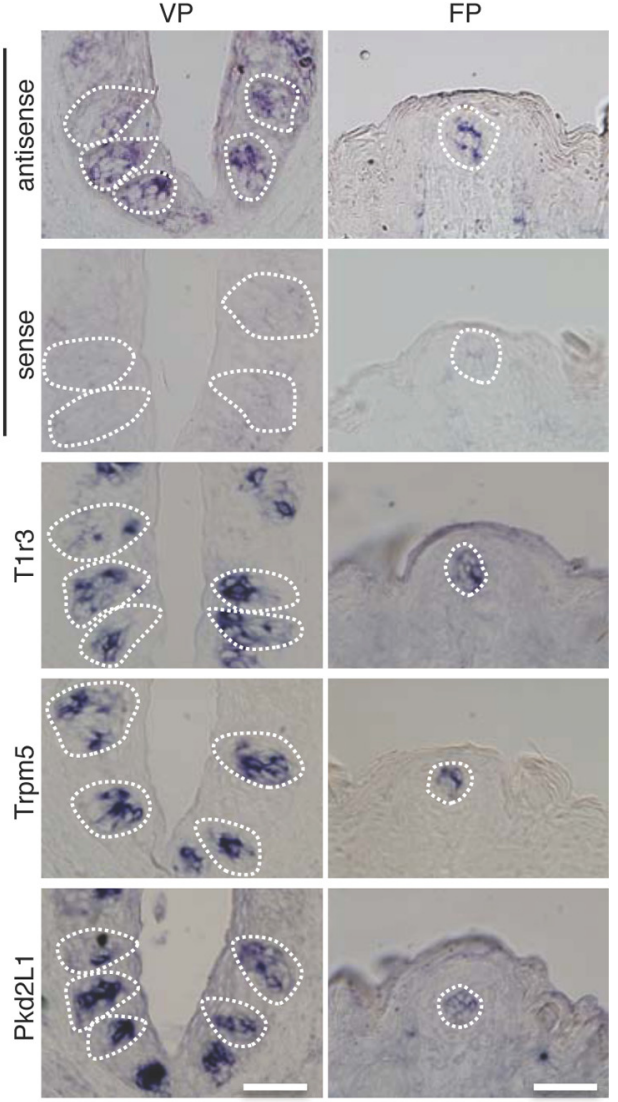

Figure 1. Angll type1 receptor (AT1) mRNA is expressed in mouse taste bud cells. A, RT-PCR amplification of AT1, AT2, Trpm5, respectively, with and without reverse transcriptase. M, 100 bp marker ladder. B, ISH detection of AT1, T1r3, Trpm5, and Pkd2L1 in FP and VP of B6 mice. The sense probe for AT1 serves as a negative control. Dotted lines indicate the outline of taste buds. Scale bar,

8 - $\mu \mathrm{m}$-thick slices, which were mounted on silane-coated glass slides. The cryosections were fixed in $4 \%$ paraformaldehyde (PFA) in PBS for 10 min at room temperature, washed with $5 \times$ standard saline citrate (SSC) for $15 \mathrm{~min}$ at room temperature, and then prehybridized in $5 \times \mathrm{SSC} / 50 \%$ formamide for $2 \mathrm{~h}$ at room temperature. Hybridization was performed in a hybridization buffer containing $50 \%$ formamide, $5 \times$ SSC, $5 \times$ Denhardt's solution, $500 \mu \mathrm{g} / \mathrm{ml}$ denatured salmon testis DNA, $250 \mu \mathrm{g} / \mathrm{ml}$ denatured baker's yeast tRNA, $1 \mathrm{~mm}$ dithiothreitol, and $20-200 \mathrm{ng} / \mathrm{ml}$ antisense RNA probe for $18 \mathrm{~h}$ at $58^{\circ} \mathrm{C}$. After hybridization, sections were washed twice in $5 \times$ SSC/50\% formamide for 5 min each and twice in $0.2 \times \mathrm{SSC} / 50 \%$ formamide for $30 \mathrm{~min}$ each at the same temperature as that used for hybridization. Subsequently, the sections were immersed in Tris-buffered saline (TBS) consisting of $50 \mathrm{~mm}$ Tris/HCl, $\mathrm{pH} 7.5$, and 150 $\mathrm{mm} \mathrm{NaCl}$ for $5 \mathrm{~min}$ at room temperature, put in the blocking solution containing $0.5 \%$ blocking reagent (Roche) in TBS for $30 \mathrm{~min}$, and incubated with anti-DIG Fab fragments conjugated with alkaline phosphatase (AP) (1:400 dilution; Roche) in the blocking solution for $60 \mathrm{~min}$ at 

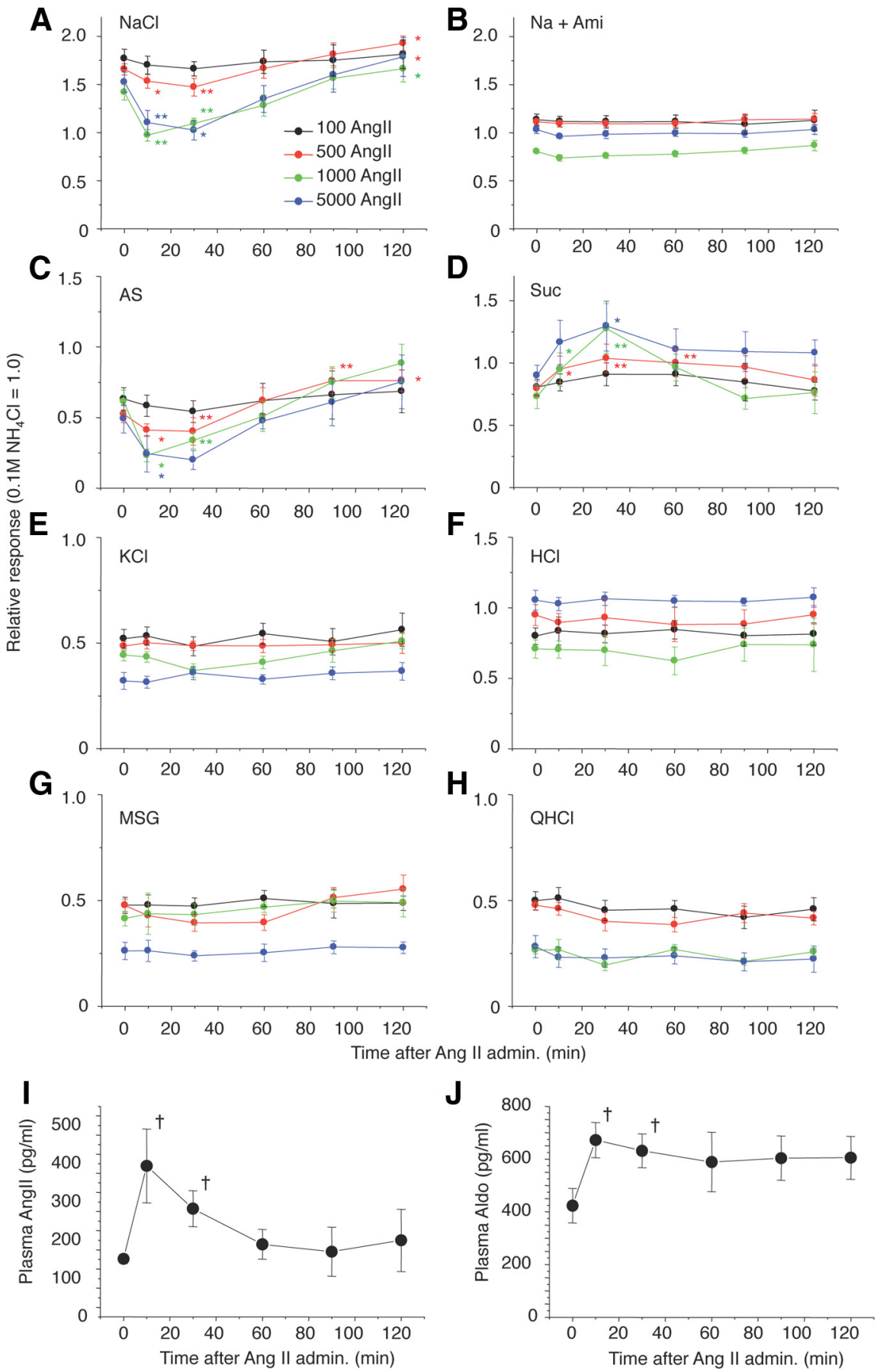

Figure 2. Time-dependent changes in CT nerve responses to ( $\boldsymbol{A}) 300 \mathrm{~mm} \mathrm{NaCl} ;(\boldsymbol{B}) 300 \mathrm{~mm} \mathrm{NaCl}+30 \mu$ mamiloride ( $\mathrm{Na}+\mathrm{Ami}$ ); (C) AS (amiloride-sensitive component: obtained by subtracting Na + Ami from NaCl); (D) $500 \mathrm{~mm} \mathrm{Suc;} \mathrm{(E)} 100 \mathrm{~mm} \mathrm{KCl;} \mathrm{(F)} 10 \mathrm{~mm}$ $\mathrm{HCl}$; (G) $100 \mathrm{~mm} \mathrm{MSG}+30 \mathrm{Ami}$ (MSG); and $(\boldsymbol{H}) 20 \mathrm{~mm} \mathrm{QHCl} 0$ and 10,30,60, 90, and 120 min after administration of $100-5000$ $\mathrm{ng} / \mathrm{kg}$ bw of Angll in B6 mice. I, J, Time-dependent changes in plasma Angll and Aldo after administration of $5000 \mathrm{ng} / \mathrm{kg} \mathrm{bw}$ of Angll in B6 mice. Asterisks indicate significant differences from control (0 min) $\left(n=6-14,{ }^{*} p<0.05,{ }^{* *} p<0.01\right.$; paired $t$ test, ${ }^{\dagger} p<0.05 ; t$ test). All data are presented as the mean \pm SEM.

room temperature. After three washes of 5 min each in TNT buffer consisting of $50 \mathrm{~mm}$ Tris/ $\mathrm{HCl}, \mathrm{pH} 7.5,150 \mathrm{~mm} \mathrm{NaCl}$, and $0.05 \%$ Tween 20 , sections were immersed in AP buffer consisting of $100 \mathrm{~mm}$ Tris/ $\mathrm{HCl}$, $\mathrm{pH}$ 9.5, $100 \mathrm{~mm} \mathrm{NaCl}$, and $50 \mathrm{~mm} \mathrm{MgCl}_{2}$ for $5 \mathrm{~min}$. The signals were developed using nitroblue-tetrazolium chloride and 5-bromo-4-chloro3 -indolylphosphate as chromogenic substrates. Then, the reaction was stopped by rinsing the slides in Tris-EDTA buffer after which they were mounted. The signal specificities of mRNA for each gene in the taste tissues were tested by using a sense probe as a negative control.
Chorda tympani nerve recording. Whole nerve responses to lingual application of tastants were recorded from the chorda tympani (CT) nerve as described previously (Kawai et al., 2000; Damak et al., 2003; Talavera et al., 2005). Under pentobarbital anesthesia (50-60 $\mathrm{mg} / \mathrm{kg} \mathrm{bw}$ ), the trachea of each mouse was cannulated and the mouse was then fixed in the supine position with a head holder to allow dissection of the CT nerve. The right CT nerve was dissected free from surrounding tissues after removal of the pterygoid muscle and cut at the point of its entry to the bulla. The entire nerve was placed on the $\mathrm{Ag} / \mathrm{AgCl}$ electrode. $\mathrm{An}$ indifferent electrode was placed in nearby tissue. Neural activities were fed into an amplifier (K-1; Iyodenshikagaku), and monitored on an oscilloscope and audio monitor. Whole nerve responses were integrated with a time constant $1.0 \mathrm{~s}$ and recorded on a computer using a PowerLab system (PowerLab/sp4; ADInstruments). For taste stimulation of FP, the anterior one-half of the tongue was enclosed in a flow chamber made of silicone rubber. Taste solutions [ $100 \mathrm{~mm} \mathrm{NH}_{4} \mathrm{Cl}, 10-1000 \mathrm{~mm} \mathrm{NaCl}$ with and without $30 \mu \mathrm{M}$ amiloride (Ami), $100-$ $300 \mathrm{~mm} \mathrm{KCl,} \mathrm{10-1000} \mathrm{mm} \mathrm{sucrose} \mathrm{(Suc),} 500$ mm glucose (Glc), 20 mm saccharin (Sac), $1 \mathrm{~mm}$ SC45647 (SC), $10 \mathrm{~mm} \mathrm{HCl,} 20 \mathrm{~mm}$ quinine$\mathrm{HCl}(\mathrm{QHCl})$, and $100 \mathrm{~mm}$ monosodium glutamate with $30 \mu \mathrm{M}$ Ami (MSG)] were delivered to each part of the tongue by gravity flow and flowed over the tongue for $30 \mathrm{~s}$. The tongue was washed with distilled water for an interval of $\sim 1$ min between successive stimulation. After the series of stimulations with amiloride, 10 $1000 \mathrm{~mm} \mathrm{NaCl}$ without amiloride was repeatedly applied to check the recovery after amiloride inhibition. In most cases of whole nerve recording, after confirming the recovery ( $>85 \%$ of control levels of responses), these series of simulations were repeated. After recording a series of control responses, each mouse was administrated a single intraperitoneal injection of $0 \mathrm{ng} / \mathrm{kg}$ bw, $100 \mathrm{ng} / \mathrm{kg}$ bw, 300 $\mathrm{ng} / \mathrm{kg}$ bw, $500 \mathrm{ng} / \mathrm{kg}$ bw, $1000 \mathrm{ng} / \mathrm{kg}$ bw, or $5000 \mathrm{ng} / \mathrm{kg}$ bw of AngII dissolved in vehicle (physiological saline). The recording of taste responses was continued until a particular point of time $(5-10,30,60,90$, and $120 \mathrm{~min}$ after injection). The AT1 receptor antagonist CV11974 (Kinugawa et al., 1993, a gift from Takeda Chemical Industries) is a potent longacting metabolite of candesartan cilexetil and causes prolonged inhibition (from $30 \mathrm{~min}$ to at least $6 \mathrm{~h}$ ) of the vasoconstrictor effects of AngII after a single intravenous injection ( $\mathrm{Li}$ and Widdop, 1995). CV11974 dissolved in vehicle (physiological saline) was given to separate group of mice (100 $\mu \mathrm{g} / \mathrm{kg}$ bw, i.v.). Beginning 90 min after injection with CV11974 and completed within $6 \mathrm{~h}$, a series of control responses, and test responses after administration of AngII, were recorded. A recording was considered to be stable when magnitudes of $0.1 \mathrm{M} \mathrm{NH}_{4} \mathrm{Cl}$ response at the beginning and end of each stimulation series deviated by no more than $15 \%$. Only responses from stable recordings were used in data analysis. In the analysis of whole nerve responses, integrated whole nerve response magnitudes were measured 5, 10, 15, 20, and $25 \mathrm{~s}$ after stimulus onset, averaged, and normalized to responses to $100 \mathrm{mM} \mathrm{NH}_{4} \mathrm{Cl}$ to account for mouse- 
to-mouse variations in absolute responses. The CT nerve responses to taste compounds 10-30 min after administration of vehicle or AngII (showing maximal effects of AngII) was used for statistical analysis (repeated ANOVA and the Fisher's PLSD as post hoc test, or Student's $t$ test).

Behavioral test. We used short-term (10 s) tests for studying the AngII effects on behavioral responses. Details of procedures for this test were described in our previous paper $(\mathrm{Mu}-$ rata et al., 2003; Shigemura et al., 2004; Yoshida et al., 2010). Each animal with $23 \mathrm{~h}$ water deprivation was placed in a test box on day 1 of training and given free access to distilled water during a $1 \mathrm{~h}$ session. The licks were detected by a lick meter with a laser beam lick sensor (Yutaka Electronics) and recorded on a strip chart recorder. Days $2-5$ were the training session. During this period, the animal was trained to drink distilled water on an interval schedule, consisting of $10 \mathrm{~s}$ periods of presentation of the distilled water alternated with $20 \mathrm{~s}$ intervals. From day 6, the number of licks for each test stimuli and distilled water given by each animal were counted during the first $10 \mathrm{~s}$ after the animal's first lick. Measurements of the number of licks were made in the following four experimental groups; intraperitoneal injection with (1) vehicle (physiological saline) as a control group on days $6-8$, (2) $5000 \mathrm{ng} / \mathrm{kg}$ bw of AngII dissolved in vehicle on the days 9-11, (3) vehicle after pretreatment with CV11974 (100 $\mu \mathrm{g} / \mathrm{kg}$ bw, i.v.) on days 12-14, and (4) 5000 $\mathrm{ng} / \mathrm{kg}$ bw of AngII dissolved in vehicle after treatment with CV11974 (100 $\mu \mathrm{g} / \mathrm{kg}$ bw, i.v.) on the days 15-17. Recording time period was chosen according to electrophysiological experiments, which demonstrated that the AngII effects of taste nerve responses started $\sim 10 \mathrm{~min}$ after the AngII injection and continued for $\sim 20 \mathrm{~min}$. On each test day, the first test stimulus given to the animal was distilled water. Then $\mathrm{NaCl}(10-1000 \mathrm{~mm})$ and $\mathrm{KCl}(10-1000$ $\mathrm{mm}$ ) series on days 6, 9, 12, and 15; $\mathrm{QHCl}$ $(0.01-3.0 \mathrm{~mm})$ and mixtures of Suc $(10-1000$ $\mathrm{mm}$ ) with $0.5 \mathrm{~mm} \mathrm{QHCl}(0.5 \mathrm{Q})$ on days 7, 10, 13 , and 16; and $\mathrm{NaCl}(10-1000 \mathrm{~mm})$ with 30 $\mu \mathrm{M}$ Ami on days $8,11,14$, and 17 , were tested in a descending order. After these measurements, the remaining test stimuli $(3$ and $10 \mathrm{~mm} \mathrm{HCl}$, the mixture of $0.5 \mathrm{~mm}$ Qui with 500 and $1000 \mathrm{~mm}$ Glc, 1 and $10 \mathrm{~mm} \mathrm{Sac}$, 0.01 and $0.3 \mathrm{~mm} \mathrm{SC}$, and $100 \mathrm{~mm}$ MSG with $30 \mu \mathrm{M} \mathrm{Ami}$ ) were tested in a randomized order on days 6-17. As the concentration of $\mathrm{QHCl}$ for Q-sweet or Q-umami mixture, we chose $0.5 \mathrm{~mm}$, because good concentration-response curves for Qui-sweet stimuli mixtures were obtained. Within this time period, testing continued until the mice no longer licked the distilled water within $7 \mathrm{~s}$ after the animal's first lick on a certain trial. The mean number of licks was obtained for each of the test stimuli in each animal. Data are shown as means \pm SE. Comparisons between groups were made using Fisher's PLSD or Student's $t$ test as post hoc test preceded by repeated two-way ANOVA. The level of significance was taken as $p<0.05$. Statistical comparisons were made using IBM SPSS Statistics.

Measurements of plasma AngII and Aldo. After anesthetizing the mice, $\sim 900 \mu$ l of blood was collected via closed chest cardiac puncture in tubes containing $10 \mathrm{U}$ heparin, $100 \mu \mathrm{M}$ amastatin (Sigma), $100 \mu \mathrm{M}$ bestatin (Cayman Chemical), and $1 \mathrm{mg} / \mathrm{kg}$ bw captopril (Sigma), and immediately placed on ice. After centrifugation at $5000 \mathrm{~g}$ for $5 \mathrm{~min}$ at $4^{\circ} \mathrm{C}$, the mean \pm SEM.
B
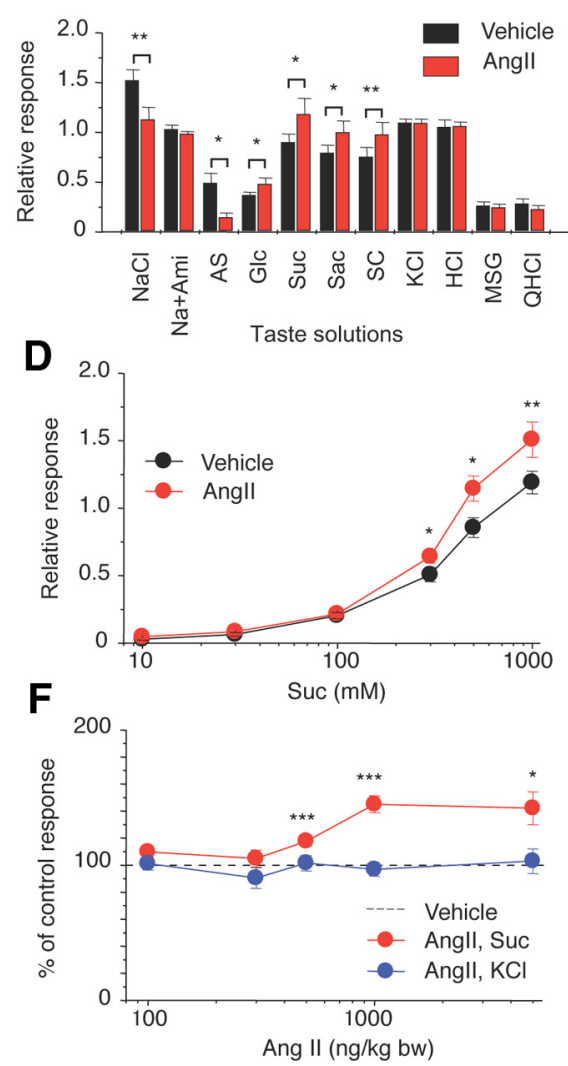

Figure 3. Angll reduces $\mathrm{CT}$ nerve responses to $\mathrm{NaCl}$ (amiloride-sensitive component) and enhances responses to sweeteners. $\boldsymbol{A}$, Typical examples of CT nerve responses of B6 mice 30 min after intraperitoneal injection of $1000 \mathrm{ng} / \mathrm{kg} \mathrm{bw}$ of Angll (lower traces) 作 SC45647]; KCl [100 mm KCl]; HCl [10 mm HCl]; MSG [100 mm monosodium glutamate + 30 Ami]; and QHCl [20 mm quinine HCl]. C, or $1000 \mathrm{ng} / \mathrm{kg}$ bw of Angll (red symbols) ( $n=5-12$ ). $\boldsymbol{D}$, Concentration-dependent CT responses to sucrose $10-30 \mathrm{~min}$ after (black symbols) or $1000 \mathrm{ng} / \mathrm{kg}$ bw of Angll (red symbols) $(n=12)$. $\boldsymbol{E}$, Dose-dependent effect of Angl case the response magnitude to $300 \mathrm{~mm} \mathrm{NaCl}, 300 \mathrm{~mm} \mathrm{Na}+30 \mu \mathrm{M} \mathrm{Ami}$, or $300 \mathrm{~mm}$ AS after administration of vehicle control were to be $100 \%$ ). Asterisks indicate significant differences between Angll treatments and vehicle controls $\left[{ }^{*} p<0.05 ;{ }^{* *} p<0.01\right.$; ${ }^{* * *} p<0.001$; paired $t$ test $(\boldsymbol{B})$, post hoc $t$ test following repeated tw0-way ANOVA $\left.(\boldsymbol{C}-\boldsymbol{F})\right]$. All data are presented as the

plasma was isolated and stored at $-80^{\circ} \mathrm{C}$ until analysis. Plasma AngII and Aldo levels were measured using an AngII EIA kit (RayBiotech) and an aldosterone ELISA kit (Alpha Diagnostic), respectively, according to the instructions provided by the manufacturer.

Immunohistochemistry. Immunohistochemistry was performed as described previously (Yoshida et al., 2010). Dissected tongues of B6, T1r3GFP, or Trpm5-GFP mice were fixed in 4\% PFA in PBS for 30-45 min at $4^{\circ} \mathrm{C}$. After dehydration with sucrose solution $(10 \%$ for $1 \mathrm{~h}, 20 \%$ for $1 \mathrm{~h}$, and $30 \%$ for $3 \mathrm{~h}$ at $4^{\circ} \mathrm{C}$ ), the frozen block of fixed tongue was embedded in OCT compound (Sakura Finetechnical) and sectioned into $8-\mu \mathrm{m}-$ thick slices, which were mounted on silane-coated glass slides and air dried. The sections were washed with TNT buffer, treated with $1 \%$ blocking reagent (Roche) for $1 \mathrm{~h}$ at room temperature, and incubated overnight at $4^{\circ} \mathrm{C}$ with primary antibodies for AT1 (1:100 dilution, sc-1173; Santa Cruz Biotechnology) and Pkd2L1 (Ishimaru et al., 2006), GLAST (1:1000, AB1782; Millipore), or ENaC (1:100, AB3530P; Millipore) in $1 \%$ blocking reagent. After washing with TNT buffer, tissues were incubated for $2 \mathrm{~h}$ at room temperature with secondary antibodies in $1 \%$ 
A

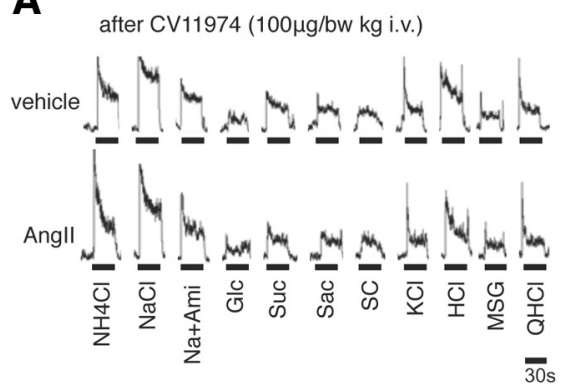

C

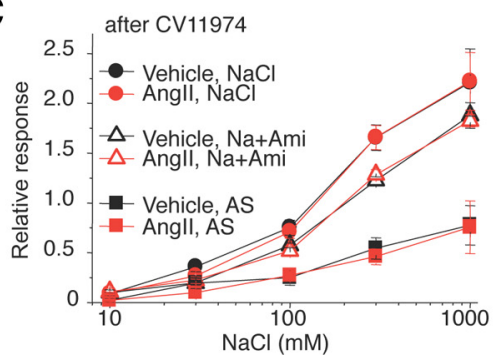

B

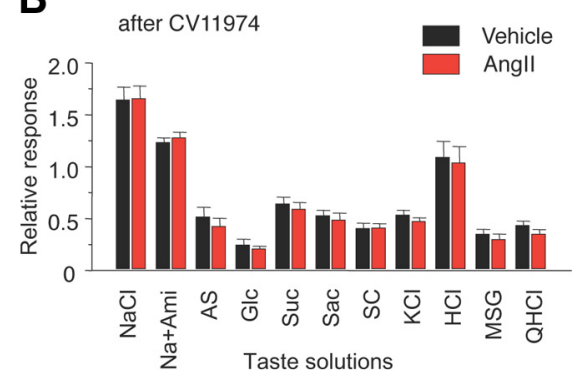

D

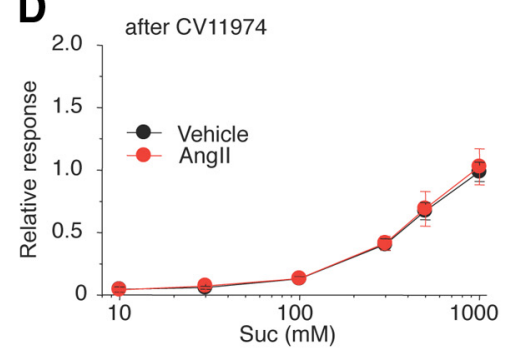

Figure 4. AT1 antagonist, CV11974, blocks the effects of Angll on gustatory nerve responses to NaCl (amiloride-sensitive component) and sweeteners. $A$, Typical examples of (T nerve responses of B6 mice pretreated with $100 \mu \mathrm{g} / \mathrm{kg}$ bw of CV1 1974 (i.v.) $30 \mathrm{~min}$ after intraperitoneal injection of $1000 \mathrm{ng} / \mathrm{kg} \mathrm{bw}$ of Angll (lower traces) versus vehicle-injected controls (upper traces). $\boldsymbol{B}$, After CV11974 treatment, CT nerve responses (normalized to $100 \mathrm{~mm} \mathrm{NH}_{4} \mathrm{Cl}$ ) of B6 mice stimulated by salty [ $\mathrm{NaCl}, 300 \mathrm{~mm} \mathrm{NaCl} ; \mathrm{Na}$ + Ami, $300 \mathrm{~mm} \mathrm{NaCl}+30 \mu$ m amiloride; $\mathrm{AS}$, amiloride-sensitive component (obtained by subtracting $\mathrm{Na}+$ Ami from NaCl); $\mathrm{KCl}$, $100 \mathrm{~mm} \mathrm{KCl}$ ), sweet (Glc, 500 mm glucose; Suc, 500 mm sucrose; Sac, 20 mm saccharin; SC, 1 mm SC45647), sour (HCl, 10 mm HCl), umami (MSG, $100 \mathrm{~mm}$ monosodium glutamate $+30 \mathrm{Ami})$, and bitter ( $\mathrm{QHCl}, 20 \mathrm{~mm}$ quinine-HCl) compounds $10-30 \mathrm{~min}$ after administration of vehicle as control (black bars) or $1000 \mathrm{ng} / \mathrm{kg}$ bw of Angll (red bars) $(n=5-8)$. C, $D$, Concentration dependence of (T responses to $\mathrm{NaCl}, \mathrm{Na}+\mathrm{Ami}, \mathrm{AS}$, and Suc $10-30 \mathrm{~min}$ after administration of vehicle (black symbols) or $1000 \mathrm{ng} / \mathrm{kg}$ bw of Angll (red symbols) with pretreatment of $100 \mu \mathrm{g} / \mathrm{kg}$ bw of CV11974 $(n=5-8)$. Significant differences were not detected from control [paired $t$ test $(\boldsymbol{B})$, repeated two-way ANOVA $(\boldsymbol{C}, \boldsymbol{D})]$. All data are presented as the mean \pm SEM.

blocking reagent, and incubated for $30 \mathrm{~min}$ at room temperature with tyramide-Alexa 488 substrate (TSA kit no. 22; Invitrogen). After washing with TNT, tissues were incubated with AP buffer for 5 min at room temperature and with HNPP/FastRed AP substrate (HNPP fluorescent detection kit; Roche) for $40 \mathrm{~min}$ at room temperature. The immunofluorescence of labeled cells and GFP fluorescence were observed by using a laser scanning microscope (FV-1000; Olympus) and images were obtained by using Fluo-view software (Olympus). To examine the number of cells expressing AT1, $\alpha \mathrm{ENaC}$, T1r3-GFP, Pkd2L1, GLAST, and Trpm5-GFP, we counted positive cells in each taste bud in horizontal sections of FP and VP. Image-Pro Plus (v4.0; Media Cybernetics) was used to exclude artifactual signals: cells showing a density signal greater than the mean plus two SDs of the density in taste cells in the negative control (primary antibodies omitted) were considered positive. The same cells found on the contiguous sections were counted only once.

\section{Results}

\section{RT-PCR}

Expression of AT1 mRNA in taste cells in B6 mice was examined by RT-PCR. As shown in Figure 1A, a band of the correct size (638 bp) was evident in taste papillae. AT1 mRNAs were expressed in FP and VP, but not in epithelial tissue (ET) devoid of taste buds. Similarly, RT-PCR products for the type II taste cell marker Trpm5 (368 bp) and the type III taste cell marker/sour receptor candidate Pkd2L1 (380 bp) were also found in FP and VP, but not in ET. As a positive control, $\beta$-actin mRNAs (360 bp) were detected in all tissues. AT2 was not expressed in any of these tissues. All control experiments in which the reverse transcriptase enzyme was omitted $(\mathrm{RT}-$ ) yielded negative results.

\section{ISH}

By ISH AT1 mRNA was detected in B6 mice in a subset of cells in FP and VP but not in surrounding epithelial cells, although the signal detected was much less intense than that for sweet/umami receptor component T1r3, Trpm5, and Pkd2L1 (Fig. 1B). Control hybridization using an AT1 sense probe was negative. These results, together with the data from RT-PCR, strongly suggest that AT1, but not AT2, is expressed in mouse taste bud cells of both the anterior and posterior tongue.

\section{CT nerve responses}

We examined effects of AngII on gustatory nerve responses to various taste stimuli and potential involvement of AT1 receptors in B6 mice. Previous nerve recording studies in rodents indicate the existence of amiloride-sensitive and -insensitive $\mathrm{NaCl}$ currents (Ninomiya and Funakoshi, 1988; Hettinger and Frank, 1990; Ninomiya, 1998; Yasumatsu et al., 2003). Both subtypes of currents were detected in B6 mice in taste buds in FP innervated by the CT nerve. In contrast, taste buds of VP and foliate papillae located on the posterior one-third of the tongue, innervated by the glossopharyngeal nerve, have very few amiloridesensitive currents. We therefore focused on B6 mouse CT nerve responses with both amiloride-sensitive and -insensitive components. We recorded CT taste responses before and after intraperitoneal administration of vehicle (physiological saline) or AngII. The CT nerve responses of B6 mice to $\mathrm{NaCl}$ started to decrease $\sim 5$ min after intraperitoneal injection of AngII, then reached near maximum suppression ( $\sim 70 \%$ of control before AngII) $\sim 30 \mathrm{~min}$ after the injection, followed by recovery [Figs. $2 A, 3 A-C\left(\mathrm{NaCl}: F_{(1,118)}=31.1, p<\right.$ $0.01)]$. Recovery of the responses to near control levels took $>1 \mathrm{~h}$ after the injection (Fig. 2A). In contrast, AngII had no such effect on responses to $\mathrm{NaCl}$ in the presence of $30 \mu \mathrm{M}$ amiloride [Figs. $2 B, 3 A-C\left(\mathrm{Na}+\right.$ Ami: $\left.F_{(1,96)}=3.80, p>0.05\right), 3 \mathrm{E}(\mathrm{Na}+\mathrm{Ami}:$ $\left.\left.F_{(1,98)}=1.08, p>0.1\right)\right]$. Thus, most of the effect of AngII was on amiloride-sensitive salt responses [Figs. $2 C, 3 B, C\left(\mathrm{AS}: F_{(1,83)}=\right.$ 24.3, $p<0.01)$ ]. Surprisingly, a significant enhancing effect of AngII on sweet responses was observed at $10-30 \mathrm{~min}$ postinjection [Figs. $2 D, 3 A, B$; (Glc, Suc, Sac, SC), $3 D\left(F_{(1,132)}=14.0, p<\right.$ $0.01)$ ], followed by recovery to the control level at $60-120 \mathrm{~min}$ postinjection (Fig. 2D). The effect of AngII on the taste responses was dose dependent and saturated at $\sim 1000 \mathrm{ng} / \mathrm{kg}$ bw AngII [Figs. $2 A, C, D, 3 E\left(\mathrm{NaCl}: F_{(1,94)}=35.3\right.$, AS: $F_{(1,82)}=14.1, p<$ 0.01 ), $3 F$ (Suc: $\left.\left.F_{(1,108)}=9.57, p<0.01\right)\right]$. AngII did not affect CT responses to $\mathrm{KCl}$, sour $(\mathrm{HCl})$, umami $(\mathrm{MSG})$, or bitter $(\mathrm{QHCl})$ substances [Figs. $2 E-H, 3 A, B, F\left(\mathrm{KCl}: F_{(1,110)}=0.52, p>0.1\right)$ ], suggesting that the effect of AngII is highly specific for amiloridesensitive salt and sweet taste responses. No sex effects on the taste modulation by $1000 \mathrm{ng} / \mathrm{kg}$ bw AngII were observed [\% of control response, male vs female, $0.1 \mathrm{M} \mathrm{NaCl}: 60 \% \pm 2.4(n=7)$ vs $63 \%$ $\pm 6.1(n=5), p=0.62 ; 0.5$ м Suc: $140 \% \pm 11.3(n=6)$ vs $149 \%$ $\pm 25.3(n=5), p=0.74$, Student's $t$ test $]$. Plasma AngII and Aldo 
increased and reached near maximum levels at $\sim 10 \mathrm{~min}$ after injection. AngII declined to baseline within $\sim 60 \mathrm{~min}$ (Fig. $2 I)$. However, Aldo was still at an elevated level at $120 \mathrm{~min}$ (Fig. 2J), which may be due to increased corticotropin releasing hormone stimulated by AngII (MaserGluth et al., 1984, Yamamoto et al., 2011).

B6 mice pretreated with the specific AT1 antagonist CV11974 showed no effects of AngII to inhibit amiloride-sensitive salt responses or enhance sweet responses [Fig. $4 A-C\left(\mathrm{NaCl}: F_{(1,70)}=0.10\right.$, AS: $F_{(1,35)}=$ $0.23, \mathrm{Na}+$ Ami: $\left.F_{(1,40)}=0.007, p>0.1\right), 4 D$ (Suc: $\left.F_{(1,84)}=0.20, p>0.1\right)$ ], indicating that AngII is acting via the AT1 receptor on taste cells.

\section{Behavioral responses}

Next, we asked whether the inhibition of salt and enhancement of sweet gustatory nerve responses by AngII would alter behavioral responses of mice to these taste stimuli. We used a short-term lick test to reduce postingestive effects, and measured the number of licks (per $10 \mathrm{~s}$ ) for test stimuli 10-40 min after administration of vehicle or $5000 \mathrm{ng} / \mathrm{kg}$ bw of AngII. Numbers of licks per $10 \mathrm{~s}$ for distilled water and sweeteners at various concentrations are typically similar, within a range of $\sim 65-80$, whereas lick responses for 0.3-1.0 $\mathrm{mM} \mathrm{QHCl}$ are $\sim 15$ (Fig. $5 E$ ). To more clearly detect concentration-dependent changes in lick rates for sweeteners, we used mixtures of $0.5 \mathrm{~mm} \mathrm{QHCl}$ and sweeteners as test solutions (a sweet-bitter mixture paradigm) (Murata et al., 2003; Shigemura et al., 2004; Yoshida et al., 2010). Previous studies showed that 23-48 h water deprivation induces elevation in circulating levels of endogenous AngII (Aguilera et al., 1978; Mann et al., 1987), suggesting effects of exogenous AngII on behavioral taste responses would be weakened or not obvious in these $23 \mathrm{~h}$ water-deprived mice. Thus we also tested the effects of CV11974 on behavioral taste responses.

Administration of AngII did not affect lick rates for $\mathrm{NaCl}$ and sucrose in waterdeprived mice as shown in Figure 5, $A$ and $B$ (AngII vs Vehicle, $\mathrm{NaCl}: F_{(1,203)}=0.10$, Suc + 0.5Q: $\left.F_{(1,203)}=0.18, p>0.1\right)$. However, after CV11974 treatment, mean lick rates for $\mathrm{NaCl}$ and $\mathrm{Suc}+0.5 \mathrm{Q}$ were significantly less than those without CV11974 (Fig. 5A, B; NaCl: $F_{(3,407)}=9.04$, Suc $\left.+0.5 \mathrm{Q}: F_{(3,407)}=6.06, p<0.01\right)$. Lick rates for other sweeteners at low concentrations were also significantly reduced after CV11974 treatment (Fig. $5 F ; 500 \mathrm{~mm} \mathrm{Glc:} F_{(3,67)}=$ 3.93, $1.0 \mathrm{~mm}$ Sac: $F_{(3,59)}=3.67,0.01 \mathrm{~mm} \mathrm{SC:} F_{(3,51)}=3.11, p<$ 0.05 ), but not at high sweetener concentrations ( $1000 \mathrm{~mm} \mathrm{Glc}, 10$ mu Sac, $\left.0.3 \mathrm{~mm} \mathrm{SC}, F_{(3,67)}=0.29 \sim 1.51, p>0.1\right)$. CV11974
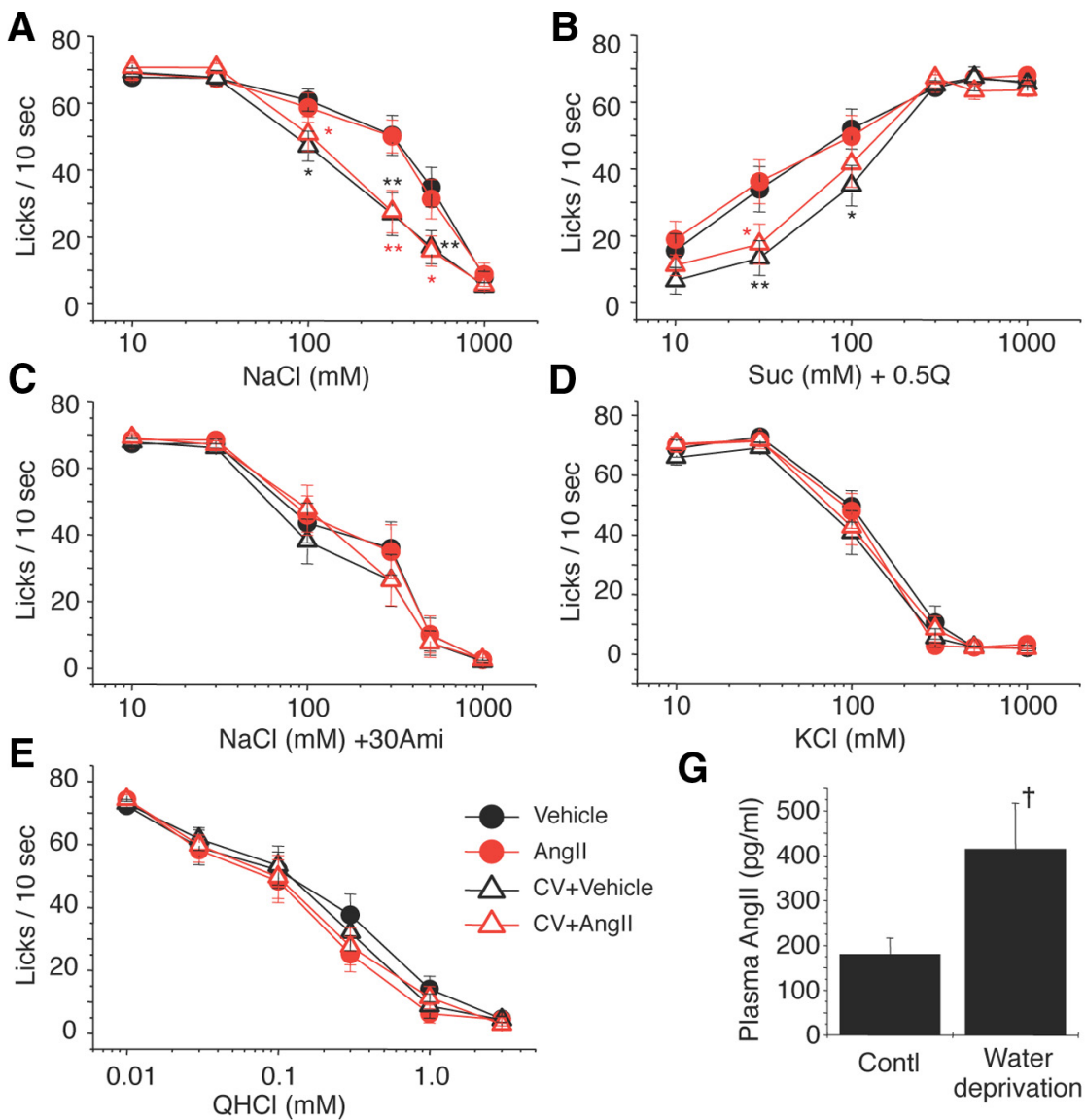

G
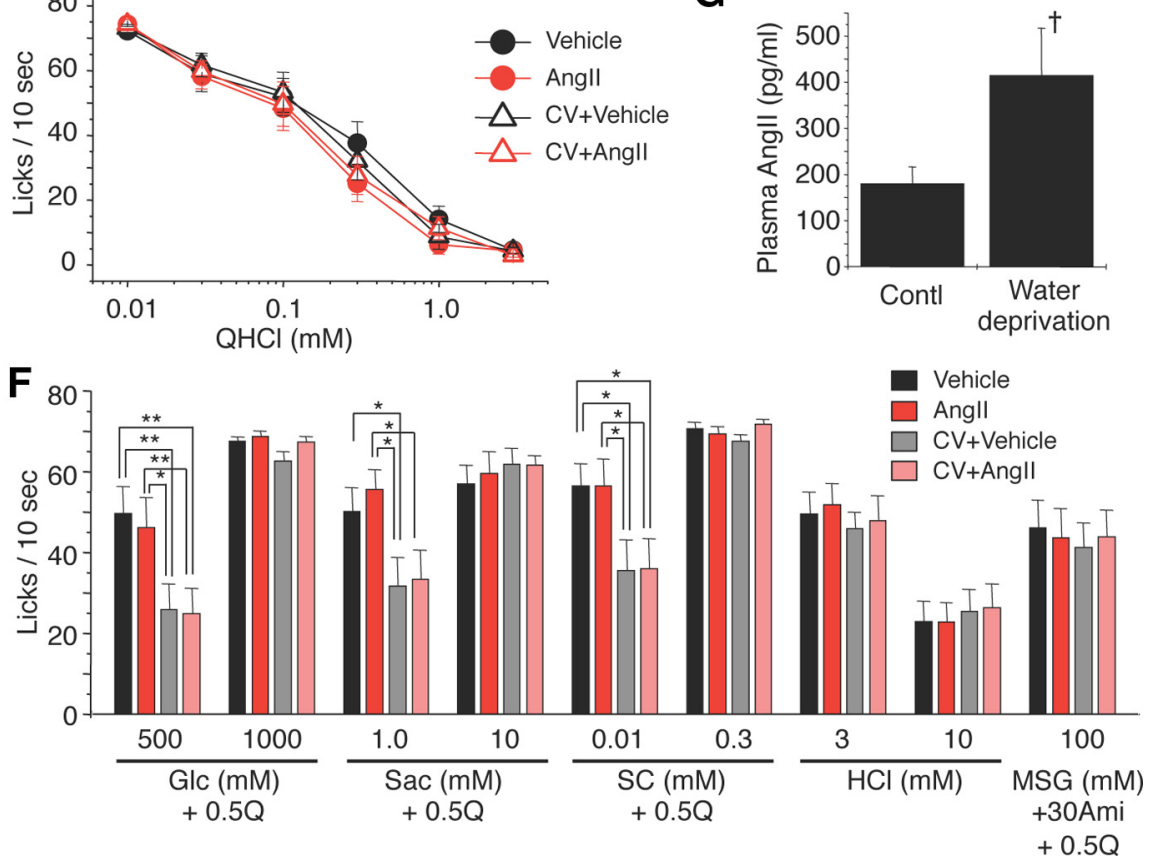

Figure 5. The AT1 antagonist CV11974 modulates behavioral responses to $\mathrm{NaCl}$ (amiloride-sensitive component) and sweeteners. Concentration-dependent lick responses to $(\boldsymbol{A}) \mathrm{NaCl}$, $(\boldsymbol{B})$ Suc $+0.5 \mathrm{Q}$ (sucrose $+0.5 \mathrm{~mm} \mathrm{QHCl}$ mixture), $(\boldsymbol{C}) \mathrm{NaCl}+30 \mathrm{Ami}$ (30 $\mu$ m amiloride), (D) KCl, and (E) $\mathrm{QHCl} 10-30 \mathrm{~min}$ after administration of vehicle (black circles), $5000 \mathrm{ng} / \mathrm{kg}$ bw of Angll (red circles), vehicle after pretreatment with $100 \mu \mathrm{g} / \mathrm{kg}$ bw of CV11974 (CV + Vehicle, black triangles), and $5000 \mathrm{ng} / \mathrm{kg}$ bw of Angll after pretreatment with $100 \mu \mathrm{g} / \mathrm{kg}$ bw of CV11974 (CV + Angll, red triangles) ( $n=17$ each). In $\boldsymbol{A}$ and $\boldsymbol{B}$, black asterisks indicate significant differences between Vehicle and CV + Vehicle. Red asterisks indicate significant differences between Angll and CV + Angll. $\boldsymbol{F}$, Lick responses to other taste stimuli: Glc (glucose) $+0.50(n=17$ each), Sac (saccharin) $+0.50(n=15-17), S C$ $(S C 45647)+0.50(n=14-17), \mathrm{HCl}(n=17$ each), MSG $+30 \mathrm{Ami}+0.50(n=17$ each) $10-30$ min after administration of vehicle (black bars), Angll (red bars), CV + Vehicle (gray bars), and CV + Angll (pink bars). G, Endogenous plasma Angll before and after $23 \mathrm{~h}$ water deprivation $\left(n=6\right.$ each). Asterisks indicate significant differences $\left({ }^{*} p<0.05\right.$; ${ }^{* *} p<0.01$; post hoc $t$ test following repeated two-way ANOVA, ${ }^{\dagger} p<0.05 ; t$ test). All data are presented as the mean $\pm \mathrm{SEM}$.

treatment and AngII did not affect lick rates for other taste stimuli [Figure 5C-E (Na + 30Ami: $F_{(3,399)}=0.81, \mathrm{KCl}: F_{(3,400)}=1.50$, QHCl: $\left.F_{(3,405)}=0.85, p>0.1\right), 5 F\left(\mathrm{HCl}: F_{(3,67)}=0.12(3 \mathrm{~mm})\right.$ and $0.26(10 \mathrm{mM}), \mathrm{MSG}+30 \mathrm{Ami}+0.5 \mathrm{Q}: F_{(3,67)}=0.096, p>$ $0.1)]$. No sex effects on the taste modulation by CV11974 were observed [\% of control response $(\mathrm{CV}+$ Ang/Ang $\times 100)$, male vs female, $300 \mathrm{~mm} \mathrm{NaCl}: 52.3 \pm 16.8 \%(n=10)$ vs $64.8 \pm 16.5 \%$ 


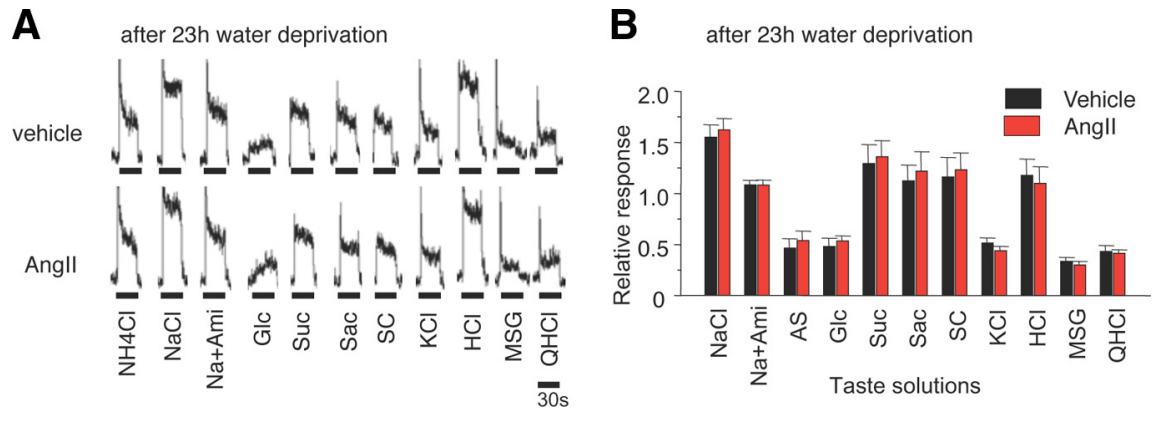

Figure 6. Twenty-three hour water-deprived B6 mice show no effects of Angll on gustatory nerve responses to $\mathrm{NaCl}$ (amiloridesensitive component) and sweeteners. $\boldsymbol{A}$, Typical examples of (T nerve responses of $23 \mathrm{~h}$ water-deprived B6 mice 30 min after intraperitoneal injection of $1000 \mathrm{ng} / \mathrm{kg}$ bw of Angll (lower traces) versus vehicle-injected controls (upper traces). $\boldsymbol{B}$, CT nerve responses (normalized to $100 \mathrm{~mm} \mathrm{NH}_{4} \mathrm{Cl}$ ) of water-deprived $\mathrm{B} 6$ mice stimulated by salty [ $\mathrm{NaCl}, 300 \mathrm{~mm} \mathrm{NaCl} ; \mathrm{Na}+\mathrm{Ami}, 300 \mathrm{~mm}$ $\mathrm{NaCl}+30 \mu \mathrm{m}$ amiloride; $\mathrm{AS}$, amiloride-sensitive component (obtained by subtracting $\mathrm{Na}+$ Ami from $\mathrm{NaCl}) ; \mathrm{KCl}, 100 \mathrm{~mm} \mathrm{KCl}$ ], sweet (Glc, 500 mm glucose; Suc, 500 mm sucrose; Sac, 20 mm saccharin; SC, 1 mm SC45647), sour (HCl, 10 mm HCl), umami (MSG, 100 mm monosodium glutamate $+30 \mathrm{Ami})$, and bitter $(\mathrm{QHCl}, 20 \mathrm{~mm}$ quinine- $\mathrm{HCl})$ compounds $10-30$ min after administration of vehicle as control (black bars) or $1000 \mathrm{ng} / \mathrm{kg}$ bw of Angll (red bars) ( $n=6$ each). Significant differences were not detected from control ( $p>0.1$, paired $t$ test). All data are presented as the mean \pm SEM.

$(n=7), p=0.62 ; 30$ mm Suc: $46.7 \pm 15.5 \%(n=9)$ vs $50.2 \pm$ $16.8 \%(n=7), p=0.88$, Student's $t$ test $]$. Endogenous plasma AngII levels were significantly elevated after $23 \mathrm{~h}$ water deprivation ( $p<0.05, n=5$, $t$ test; Fig. $5 G$ ). In these water-deprived mice, AngII had no significant effect on the CT nerve responses ( $p>0.05, n=6, t$ test; Fig. 6). These results indicate a selective modulation via AT1 in the behavioral responses to amiloridesensitive salt and sweeteners.

\section{Immunohistochemistry}

By immunohistochemistry in mice AT1 was detected in some spindle-shaped taste cells of FP and VP, but not in surrounding tissues or the gustatory nerves. Coexpression between AT1 and taste receptors was observed (Fig. 7A and Table 2). In both FP and $\mathrm{VP}$, a subset of AT1-positive cells expressed the amiloridesensitive salt taste receptor subunit $\alpha \mathrm{ENaC}$ (ENaC/AT1: 44.4 in FP and 57.0\% in VP, respectively), and the sweet/umami receptor component T1r3 in type II cells (as marked by T1r3-GFP) (T1r3/ AT1: 81.8 in FP and 79.9\% in VP), but AT1 was found in very few sour/type III cells as marked by Pkd2L1 (Pkd2L1/AT1: 4.9 in FP and $3.8 \%$ in $\mathrm{VP}$ ). The inverse coexpression ratios (AT1/marker) are shown in Table 2.

Coexpression between AT1 and other taste cell markers was also examined (Fig. 7A, Table 2). In both FP and VP, a subset of AT1-positive cells expressed the type I cell marker GLAST (GLAST/AT1: 41.0 in FP and 44.2\% in VP, respectively), or the type II cell marker Trpm5-GFP (Trpm5/AT1: 79.5 in FP and $90.9 \%$ in VP). A summary of the expression pattern of AT1 and taste cell markers in FP and VP is shown in Figure 7C. In control experiments AT1 was detected in liver hepatocytes and in kidney proximal tubule cells (Fig. $7 B$ ), consistent with previous descriptions (Gasc et al., 1994).

\section{CT nerve responses in CB1-KO mice}

Endocannabinoids have been shown to enhance sweet taste sensitivity of taste cells via CB1 endocannabinoid receptors expressed in T1r3-positive cells (Yoshida et al., 2010). It was also reported that in Chinese hamster ovary cells AT1 activation leads to CB1 activation (Turu et al., 2009). These results raised the possibility that the interaction between AT1 and CB1 in sweet taste cells would enhance sweet taste sensitivity after application of AngII. To test this possibility we examined the effects of AngII on taste responses of $\mathrm{CB} 1-\mathrm{KO}$ mice. As was observed in $\mathrm{B} 6$ mice, the $\mathrm{CT}$ nerve responses of $\mathrm{CB1}-\mathrm{KO}$ mice to $\mathrm{NaCl}$ were significantly decreased after application of AngII [Fig. $8 A-C\left(\mathrm{NaCl}: F_{(1,99)}=24.0, p<0.05\right.$, $\mathrm{Na}+$ Ami: $F_{(1,96)}=2.42, p>0.1$, AS: $\left.\left.F_{(1,94)}=11.5, p<0.05\right)\right]$. However, in contrast to the results with B6 mice, AngII had no effect on responses to sweeteners in $\mathrm{CB} 1-\mathrm{KO}$ mice [Fig. $8 A, B, D$ (Suc: $\left.\left.F_{(1,100)}=0.97, p>0.05\right)\right]$.

\section{Discussion}

In the present study AngII affected peripheral amiloride-sensitive salt and sweet taste responses measured by CT nerve recording. The effects of AngII were blocked by the AT1 receptor antagonist CV11974. AT1, but not AT2, receptors were found to be expressed in subsets of taste cells. These results suggest that the taste organ is a peripheral target of AngII, with the effects mediated by AT1 expressed in taste cells.

Behavioral analysis indicated selective decreases in the lick rates after pretreatment with CV11974 for both amiloridesensitive salt and sweeteners. These results suggest that $23 \mathrm{~h}$ water deprivation before the test may have already elevated circulating levels of endogenous AngII (Aguilera et al., 1978), which leads to reduced sensitivity to amiloride-sensitive salt and enhanced sensitivity to sweet. Such modulated taste sensitivities may be returned to basal levels by CV11974 pretreatment, consequently the mice avoid drinking concentrated $\mathrm{NaCl}$ and diluted sweet + 0.5Q mixture solutions. Indeed, in our study plasma AngII levels after water deprivation were almost the same as those at 10 min after intraperitoneal injection of AngII (Figs. 5G, 2I). In these water-deprived mice no effects of AngII on gustatory nerve responses to $\mathrm{NaCl}$ or sweet substances were observed (Fig. 6). Again, the behavioral test indicated the involvement of AT1 receptors in the AngII effects on amiloride-sensitive salt and sweet responses. Collectively, both nerve and behavioral response measurements indicate that AngII selectively suppresses amiloride-sensitive salt taste responses and enhances sweet taste responses, and that this AngII effect is mediated by its receptor, AT1.

Multiple lines of evidence from molecular studies indicate that individual taste qualities are encoded by distinct taste receptor cells (Chandrashekar et al., 2006). The present study demonstrated that AT1 receptors are coexpressed with $\alpha \mathrm{ENaC}$ (a marker for salty taste cells) or T1r3 (a marker for sweet taste cells), but not with Pkd2L1 (a marker for sour taste cells). Such expression patterns correspond to the effect of AngII shown in CT nerve responses (Figs. $2 A-H, 3 B$ ) and the effect of CV11974 shown in behavioral responses (Fig. $5 A-F$ ). It has been also reported that $\mathrm{NaCl}$ responsive taste cells in mouse fungiform taste buds are composed of both amiloride-sensitive cells that respond narrowly to $\mathrm{Na}^{+}$, and amiloride-insensitive cells that respond not only to $\mathrm{Na}^{+}$but also to $\mathrm{K}^{+}$and/or $\mathrm{H}^{+}$. Furthermore, AS cells express ENaC subunits, but not $\mathrm{G} \alpha$-gustducin (a transduction component for sweet in type II cells) or SNAP25 (synapse-related protein expressed in type III cells) (Yoshida et al., 2009). These results suggest that AngII acts to modulate amiloride-sensitive salt and sweet taste responses independently through two different subsets of taste cell-expressing $\alpha \mathrm{ENaC}$ and $\mathrm{T} 1 \mathrm{r} 3$, respectively. 
A

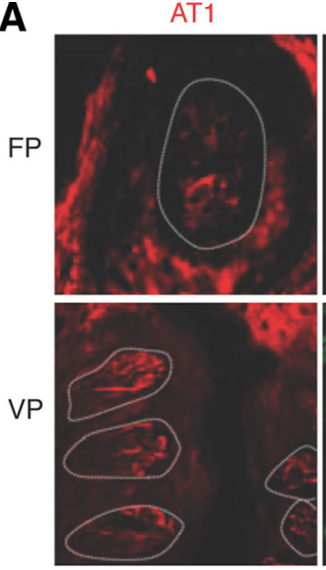

AT1

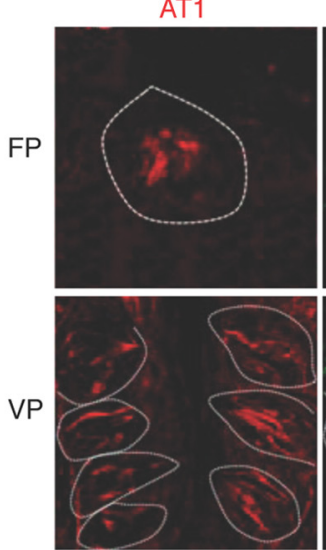

AT1

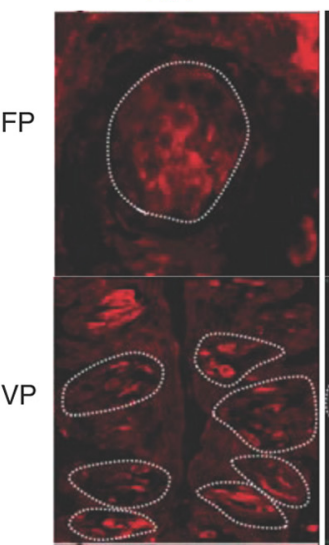

$\mathrm{aENaC}$

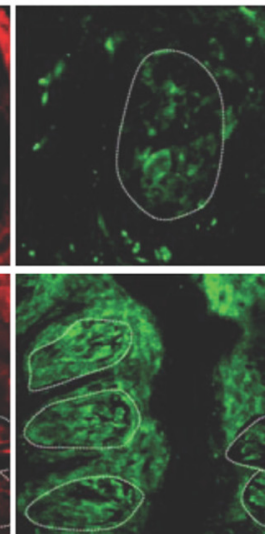

Pkd2L1

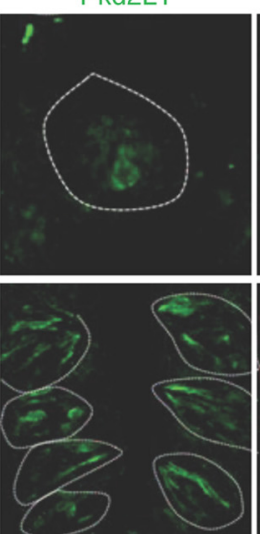

Trpm5

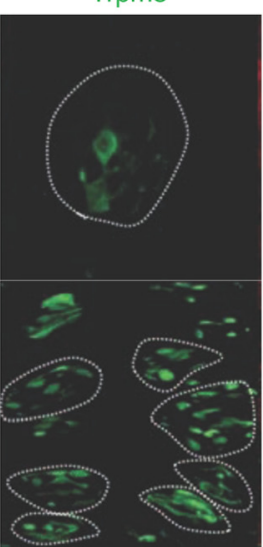

Merge
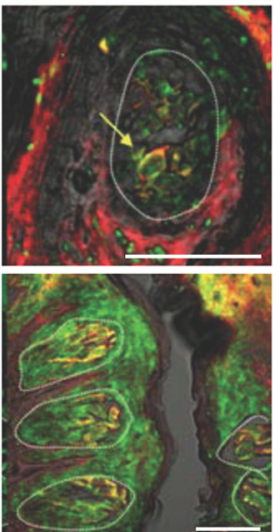

Merge

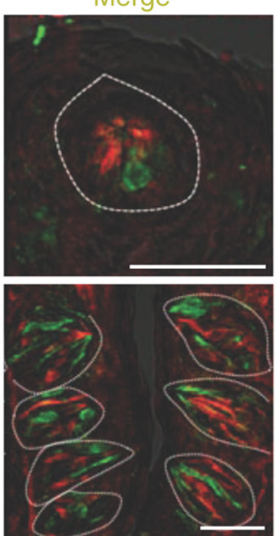

Merge

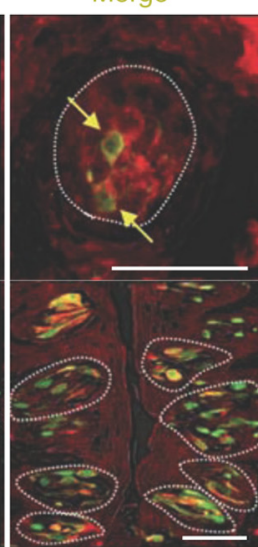

AT1

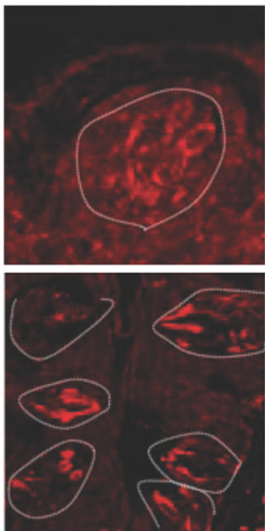

AT1

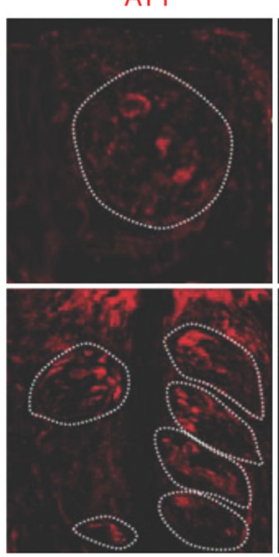

GLAST
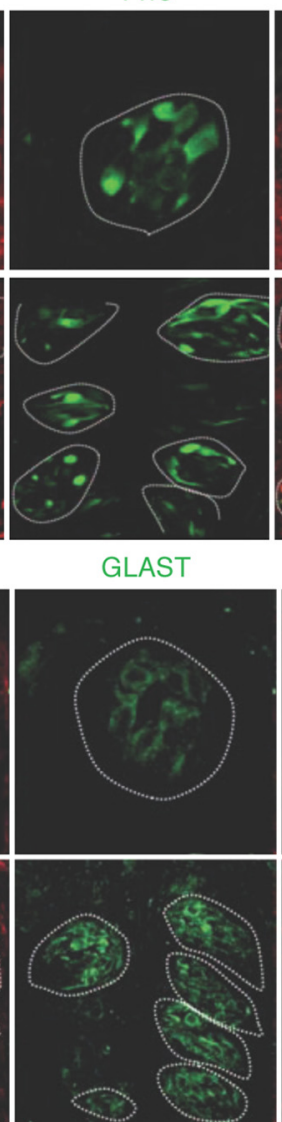

Merge

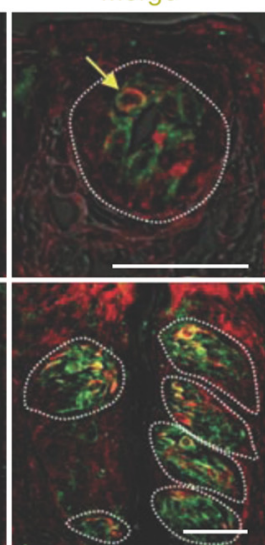

B

AT1

Kidney

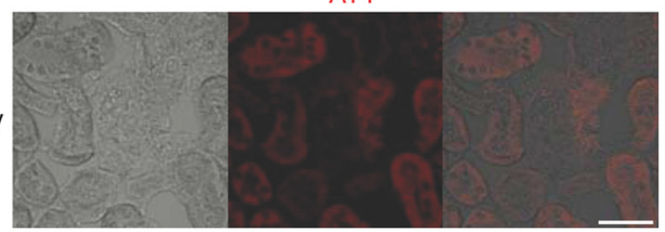

Liver

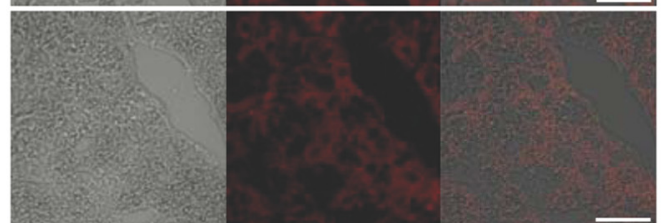

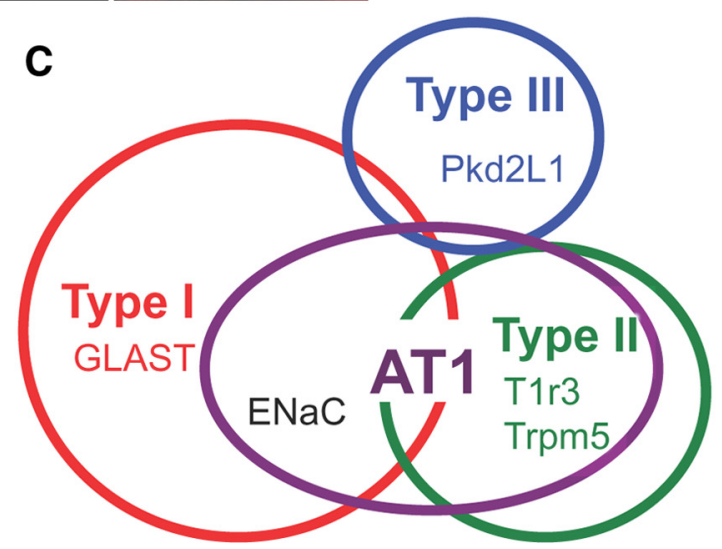

Figure 7. Coexpression in taste bud cells of AT1, $\alpha \mathrm{ENaC}$, and T1r3. A, Coexpression in FP and VP of B6, T1r3-GFP, or Trpm5-GFP mice of AT1 with $\alpha \mathrm{ENaC}$ (upper left set), T1r3 (upper right set), Pkd2L1 (middle left set), GLAST (middle right set), or Trpm5 (lower left set). Immunostaining for AT1 is shown in red. Immunostaining for $\alpha$ ENaC, Pkd2L1, GLAST, or GFP (Figure legend continues.) 
Table 2. Co-expression ratio of AT1 and taste cell markers in fungiform (FP) and circumvallate papillae (VP) in mice

\begin{tabular}{|c|c|c|c|c|c|c|c|c|c|}
\hline & FP & & VP & & & $\mathrm{FP}$ & & VP & \\
\hline$\alpha \mathrm{ENaC/AT1}$ & $44.40 \%$ & $(29 / 66, n=17)$ & $57.00 \%$ & $(53 / 93, n=27)$ & $\mathrm{AT} 1 / \alpha \mathrm{ENaC}$ & $53.70 \%$ & $(29 / 54, n=17)$ & $73.60 \%$ & $(53 / 72, n=27)$ \\
\hline T1r3/AT1 & $81.80 \%$ & $(72 / 88, n=21)$ & $79.80 \%$ & $(205 / 257, n=43)$ & $\mathrm{AT} 1 / \mathrm{T} 1 \mathrm{r} 3$ & $80.00 \%$ & $(72 / 90, n=21)$ & $71.20 \%$ & $(205 / 288, n=43)$ \\
\hline Pkd2L1/AT1 & $4.88 \%$ & $(2 / 41, n=12)$ & $3.80 \%$ & $(5 / 132, n=27)$ & AT1/Pkd2L1 & $9.52 \%$ & $(2 / 21, n=12)$ & $4.60 \%$ & $(5 / 108, n=27)$ \\
\hline GLAST/AT1 & $41.00 \%$ & $(43 / 105, n=21)$ & $44.20 \%$ & $(38 / 86, n=16)$ & AT1/GLAST & $29.70 \%$ & $(43 / 145, n=21)$ & $36.20 \%$ & $(38 / 105, n=16)$ \\
\hline Trpm5/AT1 & $79.50 \%$ & $(58 / 73, n=15)$ & $90.90 \%$ & $(140 / 154, n=24)$ & AT1/Trpm5 & $72.50 \%$ & $(58 / 80, n=15)$ & $82.80 \%$ & $(140 / 169, n=24)$ \\
\hline
\end{tabular}

$n=$ the number of taste buds examined.
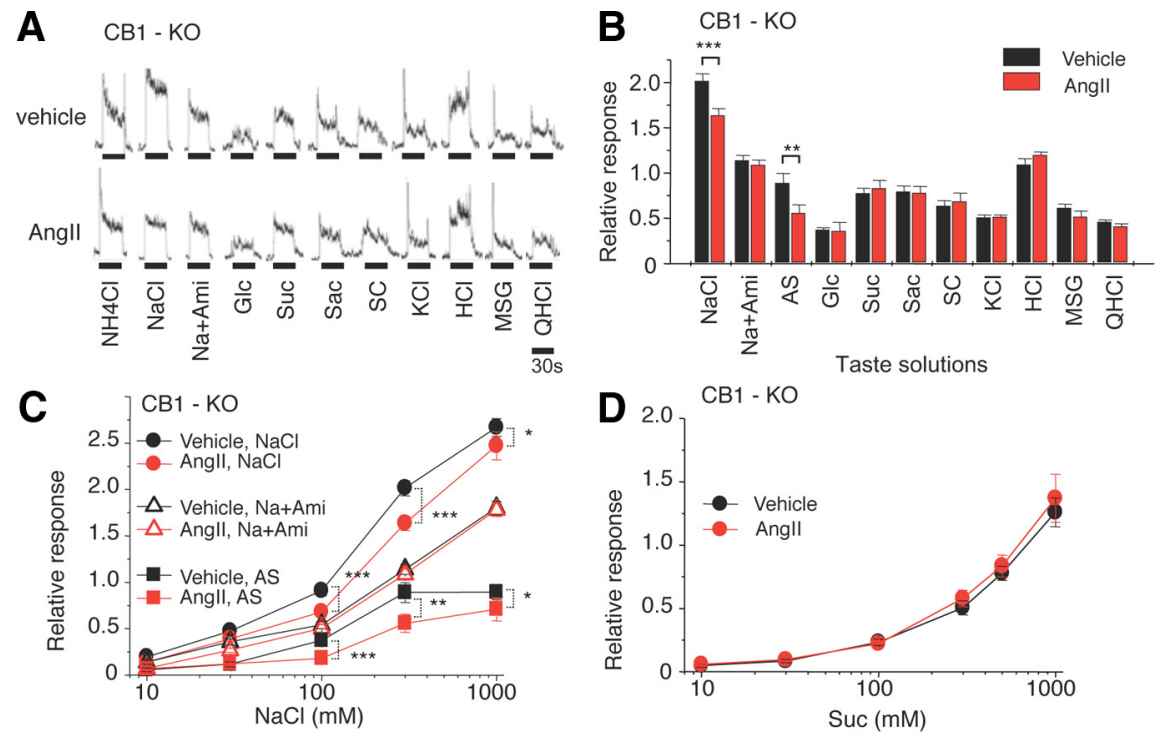

Figure 8. Sweet enhancing effect of Angll on gustatory nerve responses to sweeteners is mediated by cannabinoid receptor CB1. A, Typical examples of CT nerve responses of CB1-K0 mice $30 \mathrm{~min}$ after intraperitoneal injection of $5000 \mathrm{ng} / \mathrm{kg} \mathrm{bw}$ of Angll (lower traces) versus vehicle-injected control (upper traces). $\boldsymbol{B}, \mathrm{CT}$ nerve responses (normalized to $100 \mathrm{~mm} \mathrm{NH}_{4} \mathrm{Cl}$ ) of CB1-K0 mice stimulated by salty $[\mathrm{NaCl}, 300 \mathrm{~mm} \mathrm{NaCl} ; \mathrm{Na}+\mathrm{Ami}, 300 \mathrm{~mm} \mathrm{NaCl}+30 \mu \mathrm{m}$ amiloride; $\mathrm{AS}$, amiloride-sensitive component (obtained by subtracting $\mathrm{Na}+$ Ami from $\mathrm{NaCl}$ ); $\mathrm{KCl}, 100 \mathrm{~mm} \mathrm{KCl}$ ], sweet (Glc, $500 \mathrm{~mm}$ glucose; Suc, 500 mm sucrose; Sac, 20 mm saccharin; SC, $1 \mathrm{~mm}$ SC45647), sour ( $\mathrm{HCl}, 10 \mathrm{~mm} \mathrm{HCl})$, umami (MSG, $100 \mathrm{~mm}$ monosodium glutamate $+30 \mu \mathrm{m} \mathrm{Ami})$, and bitter (QHCl, $20 \mathrm{~mm}$ quinine-HCl) compounds $10-30$ min after administration of vehicle (black bars) or $5000 \mathrm{ng} / \mathrm{kg} \mathrm{bw}$ of Angll (red bars) $(n=11-16)$. $\boldsymbol{C}, \boldsymbol{D}$, Concentration dependence of $\mathrm{CT}$ responses to $\mathrm{NaCl}, \mathrm{Na}+\mathrm{Ami}, \mathrm{AS}$, and Suc $10-30$ min after administration of vehicle (black symbols) or $5000 \mathrm{ng} / \mathrm{kg}$ bw of Angll (red symbols) in (B1-K0 mice $(n=8-16)$. Asterisks indicate significant differences from control $\left[{ }^{*} p<0.05 ;{ }^{* *} p<0.01 ;{ }^{* * *} p<0.001\right.$; paired $t$ test $(\boldsymbol{B})$, post hoc $t$ test following repeated tw0-way ANOVA (C)]. All data are presented as the mean \pm SEM.

Amiloride-sensitive $\mathrm{NaCl}$ taste responses were observed to be suppressed by AngII 10-30 min postinjection and then recovered to control level at $60-120 \mathrm{~min}$. It is known that AngII has a half-life in circulation of $\sim 30 \mathrm{~s}$, whereas, in tissue, it may be as long as 15-30 min (van Kats et al., 1997). In our study, a short half-life of AngII was observed (Fig. 2I). The rapid effect of AngII on taste responses may be related to the short half-life of AngII. The suppressive effects of AngII on taste responses were clearly observed at 500-5000 ng/kg bw intraperitoneal injection. In the vascular system in mice, bolus intravenous injection of AngII increased blood pressure in a dose-dependent manner $\left(\mathrm{ED}_{50}=\right.$ $630 \pm 0.23 \mathrm{ng} / \mathrm{kg}$ bw) with a sharp initial peak after injection followed by a progressive return to basal level (Billet et al., 2007). This effect was proposed to be mediated by AT1 receptors. Com-

$\leftarrow$

(Figure legend continued.) fluorescence of $\mathrm{T} 1 \mathrm{r} 3$ and Trpm5 expression are shown in green. Arrows indicate AT1-expressing taste cells that coexpress $\alpha \mathrm{ENaC}$, T1r3, GLAST, or Trpm 5 in FP. Dotted lines indicate the outline of taste buds. Scale bar, $50 \mu \mathrm{m}$. $\boldsymbol{B}$, The signals for AT1 proteins are detected in hepatocytes of liver and in proximal tubule cells of kidney as described previously (Gasc et al., 1994). C, Summary of the coexpression patterns among AT1, taste receptors, and taste cell markers in $\mathrm{FP}$ and VP of mice. paring these results to our findings is difficult, because of differences in application of AngII (i.p. vs i.v.). However, the effective concentration range of AngII for inducing rapid changes in blood pressure may support our results indicating that the modulating effects of AngII on taste responses occur via AT1.

In hamster taste cells sodium currents through $\mathrm{ENaC}$ are enhanced by cAMP (Gilbertson et al., 1993). Taste cells express several isoforms of adenylyl cyclase (Abaffy et al., 2003) and phosphodiesterase (McLaughlin et al., 1994), which synthesize and degrade cAMP, respectively. The intracellular machinery for cAMP signaling is present in taste buds and cAMP changes occur following gustatory stimulation (Nakashima and Ninomiya, 1999; Roberts et al., 2009). It is also reported that AngII stimulates early proximal bicarbonate absorption by decreasing cAMP in rats (Liu and Cogan, 1989). These results suggest that the reduction of CT nerve responses to $\mathrm{NaCl}$ by AngII may be due to modulation of ENaC activity by cAMP in taste cells.

Surprisingly, AngII enhanced sweet taste responses. To date, endocannabinoids and GLP-1 are known to be enhancers of sweet taste (Shin et al., 2008; Yoshida et al., 2010). GLP-1 signaling increases both sweet and sour taste sensitivity. On the other hand, endocannabinoids selectively enhance sweet taste sensitivity via CB1 receptors on the sweet taste cells expressing T1r3. It is also reported that $\mathrm{CB} 1$ receptors are trans-activated by AT1 (Turu et al., 2009). We therefore focused on endocannabinoid-CB1 effects on sweet taste modulation by AngII. Our results showed that CT nerve responses of $\mathrm{CB} 1-\mathrm{KO}$ or $\mathrm{B} 6$ mice to $\mathrm{NaCl}$ significantly decreased after application of AngII, while AngII had no effect on responses to sweeteners in $\mathrm{CB} 1-\mathrm{KO}$ mice, suggesting that the enhancing effect of AngII on sweet taste responses is mediated by AT1 and CB1 receptors.

AngII and sweet taste compounds generally activate the phospholipase $\mathrm{C}$ signaling pathway via AT1 and T1r2 + T1r3 receptors, respectively (Wirthensohn and Guder, 1985, Chandrashekar et al., 2006), which increases release of both inositol-1,4,5,trisphosphate and diacylglycerol (DAG). DAG is hydrolyzed by DAG lipase to produce an endocannabinoid [2- arachidonoyl glycerol (2-AG)]. If such a synthetic pathway for 2-AG exists in taste cells, released 2-AG may act as an autocrine enhancer for $\mathrm{CB} 1$ receptors on sweet taste cells. The physiological role of the sweet enhancing effect of AngII may lead to increased calorie intake, which may play a role in regu- 
lating glucose homeostasis. This hypothesis may be supported by a recent study comparing the effect of AT1 receptor blockers (e.g., valsartan, losartan) versus placebo on the development of diabetes in patients with impaired glucose tolerance and cardiovascular risk factors or disease (McMurray et al., 2010). The incidence of diabetes was modestly but significantly lower in the valsartan-treated group compared with the placebo group. The linkage between salty and sweet preferences via AngII signaling, like that between sodium and glucose absorption via sodium-glucose cotransporter1 in small intestine (Ferraris and Diamond, 1993), may optimize sodium and calorie intakes.

Under sodium deficiency rats increase their intake of salt over a range of concentrations normally avoided. Sodium depletion also increases circulating levels of both AngII and Aldo (Mann et al., 1987). As evidenced by single fiber recordings, sodium deficiency apparently resulted in a selective reduction in the response rate of sodium-specialist neurons to $\mathrm{NaCl}$ (Contreras and Frank, 1979). Subsequent studies showed that these sodium specialists are sensitive to amiloride (Garcia et al., 2008). The reduction of amiloride-sensitive salt responses in the sodium-depleted animals may be mediated by AngII signaling in taste cells.

Aldo has been implicated as an enhancer of amiloridesensitive salt taste responses in taste cells (Herness, 1992; Lin et al., 1999). In the kidney, Aldo binds to the cytosolic mineralocorticoid receptor, which is translocated to the cell nucleus, and enhances the expression of $\alpha \mathrm{ENaC}$ and influences the apical targeting and function of ENaC. After Aldo injection in adrenalectomized rats $\mathrm{ENaC}$ is shifted toward the apical cellular pole and the apical plasma membrane within 2 and 4 h, respectively (Loffing et al., 2001), suggesting that the effects of Aldo on amiloride-sensitivity in taste cells occur within hours. In our study, increased amiloride-sensitive CT nerve responses to $\mathrm{NaCl}$ were observed at 90-120 min after an AngII administration (Fig. $2 A, C$ ), which may be mediated by induction of Aldo (Fig. $2 J$ ). Together, these results suggests that AngII may play a role in increasing sodium intake by rapidly reducing amiloride-sensitive salt taste responses, and subsequently Aldo may work to stop excessive salt intake by increasing amiloride-sensitive taste responses.

In summary, we have demonstrated that AngII modulates amiloride-sensitive salt and sweet taste responses. The effect of AngII on taste responses is via AT1 receptors. Expression analyses show that AT1 receptors are coexpressed with $\alpha \mathrm{ENaC}$ or T1 $1 \mathrm{r}$ in a subset of taste cells. Together, these results suggest that the taste organ is a newly appreciated peripheral target of AngII's actions, and the specific reduction of amiloride-sensitive salt taste sensitivity by AngII may contribute to increased sodium intake. The reciprocal regulation of peripheral salt taste sensitivity by AngII (suppresses) and Aldo (enhances) may play an important role in sodium homeostasis via ingestion. Furthermore, AngII may contribute to increase energy intake by enhancing sweet responses. The linkage between salty and sweet preferences via AngII signaling may optimize sodium and calorie intakes.

\section{References}

Abaffy T, Trubey KR, Chaudhari N (2003) Adenylyl cyclase expression and modulation of cAMP in rat taste cells. Am J Physiol Cell Physiol 284: C1420-C1428. Medline

Aguilera G, Hauger RL, Catt KJ (1978) Control of aldosterone secretion during sodium restriction: adrenal receptor regulation and increased adrenal sensitivity to angiotensin II. Proc Natl Acad Sci U S A 75:975-979. CrossRef Medline

Avrith DB, Fitzsimons JT (1980) Increased sodium appetite in the rat in- duced by intracranial administration of components of the renin-angiotensin system. J Physiol 301:349-364. Medline

Billet S, Bardin S, Verp S, Baudrie V, Michaud A, Conchon S, Muffat-Joly M, Escoubet B, Souil E, Hamard G, Bernstein KE, Gasc JM, Elghozi JL, Corvol P, Clauser E (2007) Gain-of-function mutant of angiotensin II receptor, type 1A, causes hypertension and cardiovascular fibrosis in mice. J Clin Invest 117:1914-1925. CrossRef Medline

Chandrashekar J, Hoon MA, Ryba NJ, Zuker CS (2006) The receptors and cells for mammalian taste. Nature 444:288-294. CrossRef Medline

Chandrashekar J, Kuhn C, Oka Y, Yarmolinsky DA, Hummler E, Ryba NJ, Zuker CS (2010) The cells and peripheral representation of sodium taste in mice. Nature 464:297-301. CrossRef Medline

Clapp TR, Medler KF, Damak S, Margolskee RF, Kinnamon SC (2006) Mouse taste cells with $\mathrm{G}$ protein-coupled taste receptors lack voltagegated calcium channels and SNAP-25. BMC Biol 4:7. CrossRef Medline

Contreras RJ, Frank M (1979) Sodium deprivation alters neural responses to gustatory stimuli. J Gen Physiol 73:569-594. CrossRef Medline

Damak S, Rong M, Yasumatsu K, Kokrashvili Z, Varadarajan V, Zou S, Jiang P, Ninomiya Y, Margolskee RF (2003) Detection of sweet and umami taste in the absence of taste receptor T1r3. Science 301:850-853. CrossRef Medline

Damak S, Mosinger B, Margolskee RF (2008) Transsynaptic transport of wheat germ agglutinin expressed in a subset of type II taste cells of transgenic mice. BMC Neurosci 9:96. CrossRef Medline

de Gasparo M, Catt KJ, Inagami T, Wright JW, Unger T (2000) International Union of Pharmacology. XXIII. The angiotensin II receptors. Pharmacol Rev 52:415-472. Medline

Ferraris RP, Diamond JM (1993) Crypt/villus site of substrate-dependent regulation of mouse intestinal glucose transporters. Proc Natl Acad Sci U S A 90:5868-56872. CrossRef Medline

Fitts DA, Thunhorst RL (1996) Rapid elicitation of salt appetite by an intravenous infusion of angiotensin II in rats. Am J Physiol 270:R1092-R1098. Medline

Garcia JM, Curtis KS, Contreras RJ (2008) Behavioral and electrophysiological taste responses change after brief or prolonged dietary sodium deprivation. Am J Physiol Regul Integr Comp Physiol 295:R1754-R1761. CrossRef Medline

Gasc JM, Shanmugam S, Sibony M, Corvol P (1994) Tissue-specific expression of type 1 angiotensin II receptor subtypes. An in situ hybridization study. Hypertension 24:531-537. CrossRef Medline

Gilbertson TA, Roper SD, Kinnamon SC (1993) Proton currents through amiloride-sensitive $\mathrm{Na}^{+}$; channels in isolated hamster taste cells: enhanced by vasopressin and cAMP. Neuron 10:931-942. CrossRef Medline

Heck GL, Mierson S, DeSimone JA (1984) Salt taste transduction occurs through an amiloride-sensitive sodium transport pathway. Science 223: 403-405. CrossRef Medline

Herness MS (1992) Aldosterone increases the amiloride-sensitivity of the rat gustatory neural response to $\mathrm{NaCl}$. Comp Biochem Physiol Comp Physiol 103:269-273. CrossRef Medline

Hettinger TP, Frank ME (1990) Specificity of amiloride inhibition of hamster taste responses. Brain Res 513:24-34. CrossRef Medline

Ishimaru $\mathrm{Y}$, Inada $\mathrm{H}$, Kubota $\mathrm{M}$, Zhuang $\mathrm{H}$, Tominaga $\mathrm{M}$, Matsunami $\mathrm{H}$ (2006) Transient receptor potential family members PKD1L3 and PKD2L1 form a candidate sour taste receptor. Proc Natl Acad Sci U S A 103:12569-12574. CrossRef Medline

Kawai K, Sugimoto K, Nakashima K, Miura H, Ninomiya Y (2000) Leptin as a modulator of sweet taste sensitivities in mice. Proc Natl Acad Sci U S A 97:11044-11049. CrossRef Medline

Kinugawa K, Kohmoto O, Takahashi T, Serizawa T (1993) Effects of a nonpeptide angiotensin II receptor antagonist $(\mathrm{CV}-11974)$ on $\left[\mathrm{Ca}^{2+}\right] \mathrm{i}$ and cell motion in cultured ventricular myocytes. Eur J Pharmacol 235:313316. CrossRef Medline

Ledent C, Valverde O, Cossu G, Petitet F, Aubert JF, Beslot F, Böhme GA, Imperato A, Pedrazzini T, Roques BP, Vassart G, Fratta W, Parmentier M (1999) Unresponsiveness to cannabinoids and reduced addictive effects of opiates in CB1 receptor knockout mice. Science 283:401-404. CrossRef Medline

Li XC, Widdop RE (1995) Regional hemodynamic effects of the AT1 receptor antagonist CV-11974 in conscious renal hypertensive rats. Hypertension 26:989-997. CrossRef Medline

Lin W, Finger TE, Rossier BC, Kinnamon SC (1999) Epithelial $\mathrm{Na}^{+}$channel 
subunits in rat taste cells: localization and regulation by aldosterone. J Comp Neurol 405:406-420. CrossRef Medline

Liu FY, Cogan MG (1989) Angiotensin II stimulates early proximal bicarbonate absorption in the rat by decreasing cyclic adenosine monophosphate. J Clin Invest 84:83-91. CrossRef Medline

Loffing J, Zecevic M, Féraille E, Kaissling B, Asher C, Rossier BC, Firestone GL, Pearce D, Verrey F (2001) Aldosterone induces rapid apical translocation of $\mathrm{ENaC}$ in early portion of renal collecting system: possible role of SGK. Am J Physiol Renal Physiol 280:F675-F682. Medline

Mann JF, Johnson AK, Ganten D, Ritz E (1987) Thirst and the reninangiotensin system. Kidney Int Suppl 21:S27-S34. Medline

Maser-Gluth C, Toygar A, Vecsei P (1984) Time course of plasma corticosterone, 18-hydroxycorticosterone and aldosterone concentrations following CRF administration in the rat. A phase of corticosterone inhibition. Life Sci 35:879-884. CrossRef Medline

McLaughlin SK, McKinnon PJ, Spickofsky N, Danho W, Margolskee RF (1994) Molecular cloning of $G$ proteins and phosphodiesterases from rat taste cells. Physiol Behav 56:1157-1164. CrossRef Medline

McMurray JJ, Holman RR, Haffner SM, Bethel MA, Holzhauer B, Hua TA, Belenkov Y, Boolell M, Buse JB, Buckley BM, Chacra AR, Chiang FT, Charbonnel B, Chow CC, Davies MJ, Deedwania P, Diem P, Einhorn D, Fonseca V, Fulcher GR, et al. (2010) Effect of valsartan on the incidence of diabetes and cardiovascular events. N Engl J Med 362:1477-1490. CrossRef Medline

Murata Y, Nakashima K, Yamada A, Shigemura N, Sasamoto K, Ninomiya Y (2003) Gurmarin suppression of licking responses to sweetener-quinine mixtures in C57BL mice. Chem Senses 28:237-243. CrossRef Medline

Nakamura Y, Sanematsu K, Ohta R, Shirosaki S, Koyano K, Nonaka K, Shigemura N, Ninomiya Y (2008) Diurnal variation of human sweet taste recognition thresholds is correlated with plasma leptin levels. Diabetes 57:2661-2665. CrossRef Medline

Nakashima K, Ninomiya Y (1999) Transduction for sweet taste of saccharin may involve both inositol 1,4,5-trisphosphate and cAMP pathways in the fungiform taste buds in C57BL mice. Cell Physiol Biochem 9:90-98. CrossRef Medline

Ninomiya Y (1998) Reinnervation of cross-regenerated gustatory nerve fibers into amiloride-sensitive and amiloride-insensitive taste receptor cells. Proc Natl Acad Sci U S A 95:5347-53450. CrossRef Medline

Ninomiya Y, Funakoshi M (1988) Amiloride inhibition of responses of rat single chorda tympani fibers to chemical and electrical tongue stimulations. Brain Res 451:319-325. CrossRef Medline

Roberts CD, Dvoryanchikov G, Roper SD, Chaudhari N (2009) Interaction between the second messengers cAMP and $\mathrm{Ca}^{2+}$ in mouse presynaptic taste cells. J Physiol 587:1657-1668. CrossRef Medline

Shigemura N, Ohta R, Kusakabe Y, Miura H, Hino A, Koyano K, Nakashima K, Ninomiya Y (2004) Leptin modulates behavioral responses to sweet substances by influencing peripheral taste structures. Endocrinology 145: 839-847. Medline

Shin YK, Martin B, Golden E, Dotson CD, Maudsley S, Kim W, Jang HJ, Mattson MP, Drucker DJ, Egan JM, Munger SD (2008) Modulation of taste sensitivity by GLP-1 signaling. J Neurochem 106:455-463. CrossRef Medline

Talavera K, Yasumatsu K, Voets T, Droogmans G, Shigemura N, Ninomiya Y, Margolskee RF, Nilius B (2005) Heat activation of TRPM5 underlies thermal sensitivity of sweet taste. Nature 438:1022-1025. CrossRef Medline

Turu G, Várnai P, Gyombolai P, Szidonya L, Offertaler L, Bagdy G, Kunos G, Hunyady L (2009) Paracrine transactivation of the CB1 cannabinoid receptor by $\mathrm{AT} 1$ angiotensin and other $\mathrm{Gq} / 11$ protein-coupled receptors. J Biol Chem 284:16914-16921. CrossRef Medline

van Kats JP, de Lannoy LM, Jan Danser AH, van Meegen JR, Verdouw PD, Schalekamp MA (1997) Angiotensin II type 1 (AT1) receptor-mediated accumulation of angiotensin II in tissues and its intracellular half-life in vivo. Hypertension 30:42-49. CrossRef Medline

Wirthensohn G, Guder WG (1985) Stimulation of phospholipid turnover by angiotensin II and phenylephrine in proximal convoluted tubules microdissected from mouse nephron. Pflügers Arch 404:94-96. CrossRef Medline

Yamamoto R, Akazawa H, Fujihara H, Ozasa Y, Yasuda N, Ito K, Kudo Y, Qin Y, Ueta Y, Komuro I (2011) Angiotensin II type 1 receptor signaling regulates feeding behavior through anorexigenic corticotropin-releasing hormone in hypothalamus. J Biol Chem 286:21458-21465. CrossRef Medline

Yasumatsu K, Katsukawa H, Sasamoto K, Ninomiya Y (2003) Recovery of amiloride-sensitive neural coding during regeneration of the gustatory nerve: behavioral-neural correlation of salt taste discrimination. J Neurosci 23:4362-4368. Medline

Yoshida R, Horio N, Murata Y, Yasumatsu K, Shigemura N, Ninomiya Y (2009) $\mathrm{NaCl}$ responsive taste cells in the mouse fungiform taste buds. Neuroscience 159:795-803. CrossRef Medline

Yoshida R, Ohkuri T, Jyotaki M, Yasuo T, Horio N, Yasumatsu K, Sanematsu K, Shigemura N, Yamamoto T, Margolskee RF, Ninomiya Y (2010) Endocannabinoids selectively enhance sweet taste. Proc Natl Acad Sci U S A 107:935-939. CrossRef Medline 